\begin{tabular}{|l|l|}
\hline $\begin{array}{l}\text { 2. To: (Receiving Organization) } \\
\text { Distribution }\end{array}$ & $\begin{array}{l}\text { 3. From: (Originating Organization) } \\
\text { Geophys ics Group }\end{array}$ \\
\hline 5. Proj./Prog./Dept./Div.: & $\begin{array}{l}\text { 6. Design Author ity/ Design Agent/Cog. } \\
\text { Engr.: } \\
\text { LES/HTS/Geophysics }\end{array}$ \\
\hline
\end{tabular}

8. Originator Remarks:

WHC-SD-EN-TI-258, Spectral Gamma-ray Logging Report for the Six New Characterization Boreholes in the 100-FR-1 Operable Unit, Rev 0

$$
\text { 11. Receiver Remarks: 11A. Design Baseline Document? [] Yes } \mathrm{W} \text { No }
$$
4. Related EDT No.:
$\mathrm{N} / \mathrm{A}$
7. Purchase Order No.:

$$
\mathrm{N} / \mathrm{A}
$$

9. Equip./Component No.:

$$
\text { N/A }
$$

10. System/Bldg./Facility: N/A

12. Major Assm. Dwg. No.: $N / A$

13. Permit/Permit Application Mo.: $N / A$

14. Required Response Date:

$N / A$

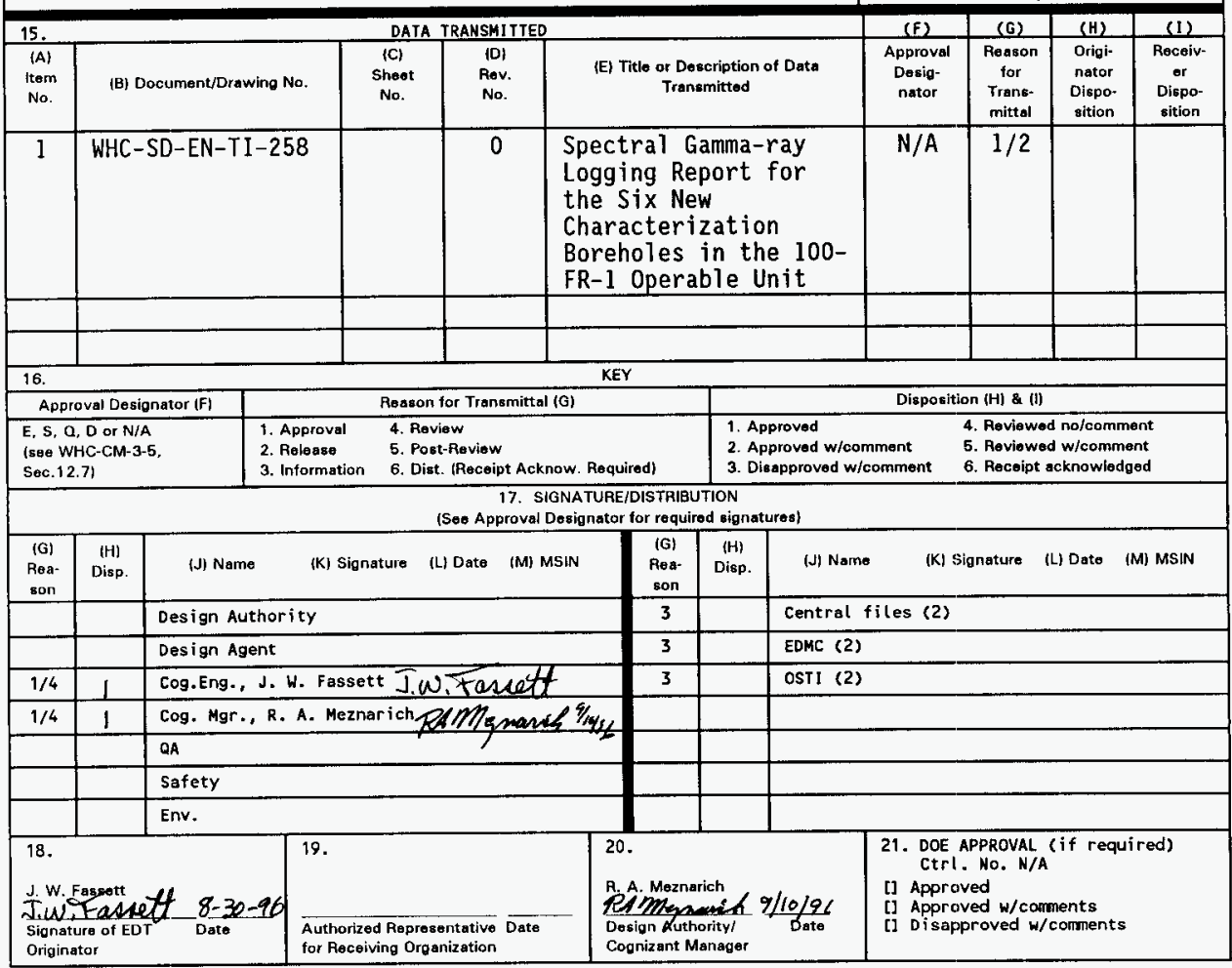

BD-7400-172-2 (05/96) GEF097 


\section{Spectral Gamma-ray Logging Report for the Six New Characterization Boreholes in the 100-FR-1 Operable Unit}

\section{G. J. Szwartz}

Westinghouse Hanford Company, Richland, WA 99352

U.S. Department of Energy Contract DE-AC06-87RL10930
EDT/ECN: 610770
UC: 630
Org Code: $8 \mathrm{H} 100$
Charge Code: R4V11
B\&R Code: EW3120100
Total Pages: 42

Key Words: Geophysics, gamma-ray, RLS, logging

Abstract: Six characterization boreholes were drilled, sampled, logged, and abandoned in the 100-FR-1 Operable Unit. The geophysical logging was carried out with the Radionuclide Logging System (RLS) to determine the levels of radioactive contaminants in the subsurface. Five of the six boreholes penetrated contamination that was successfully assayed with the RLS data.

TRADEMARK DISCLAIMER. Reference herein to any specific commercial product, process, or service by trade name, trademark, manufacturer, or otherwise, does not necessarily constitute or imply its endorsement, recommendation, or favoring by the United States Government or any agency thereof or its contractors or subcontractors.

Printed in the United States of America. To obtain copies of this document, contact: WHC/BCS Document Control Services, P.O. Box 1970, Mailstop H6-08, Richland WA 99352, Phone (509) 372-2420; Fax (509) 376-4989.
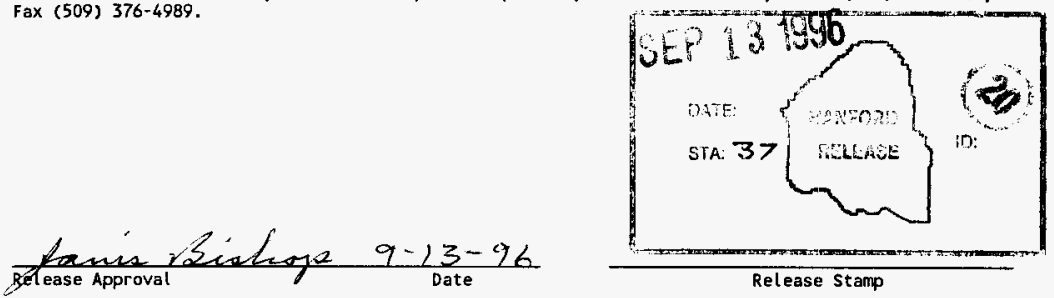

\section{Approved for Public Release}


WHC-SD-EN-TI-258, Rev 0

\section{CONTENTS}

1.0 INTRODUCTION $\ldots \ldots \ldots \ldots \ldots \ldots \ldots \ldots \ldots \ldots \ldots \ldots \ldots \ldots \ldots$

2.0 SITE SETTING $\ldots \ldots \ldots \ldots \ldots \ldots \ldots \ldots \ldots \ldots \ldots \ldots \ldots \ldots \ldots \ldots$

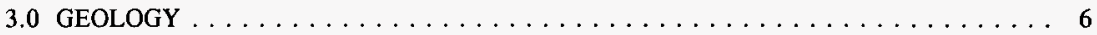

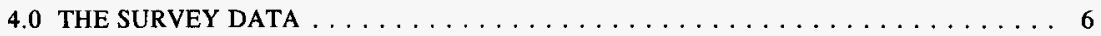

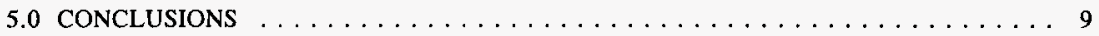

6.0 FUTURE CONSIDERATIONS $\ldots \ldots \ldots \ldots \ldots \ldots \ldots \ldots \ldots \ldots$

7.0 REFERENCES $\ldots \ldots \ldots \ldots \ldots \ldots \ldots \ldots \ldots \ldots \ldots \ldots \ldots \ldots \ldots \ldots$

APPENDICES

A RLS SURVEY DATA AND SPECTRAL GAMMA PLOTS $\ldots \ldots \ldots \ldots \ldots \ldots \ldots \ldots$

B THE RLS SYTEM $\ldots \ldots \ldots \ldots \ldots \ldots \ldots \ldots \ldots \ldots \ldots \ldots \ldots \ldots \ldots$

\section{FIGURES}

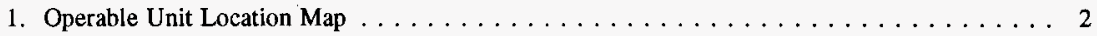

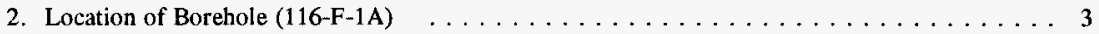

3. Location of Boreholes $(116-\mathrm{F}-2,116-\mathrm{F}-9 \mathrm{C}, \& 116-\mathrm{F}-14) \ldots \ldots \ldots \ldots \ldots$

4. Location of Boreholes $(116-\mathrm{F}-4$ \& $116-\mathrm{F}-6) \quad \ldots \ldots \ldots \ldots \ldots \ldots$ 


\section{WHC-SD-EN-TI-258, Rev 0}

\section{TABLES}

1. Summary of Maximum Radionuclide Depths from RLS Log Surveys of the $100-F R-1$ Operable Unit $\ldots \ldots \ldots \ldots \ldots \ldots \ldots \ldots \ldots$

2. Summary of Cesium-137 Detected from RLS Log Surveys

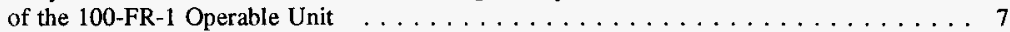

3. Summary of the Cobalt-60 Detected from RLS Log Surveys of the $100-$ FR-1 Operable Unit $\ldots \ldots \ldots \ldots \ldots \ldots \ldots \ldots \ldots \ldots$

4. Summary of Eruopium-152 Detected from RLS Log Surveys of the 100-FR-1 Operable Unit . . . . . . . . . . . . . . . . 8

5. Summary of Europium-154 Detected from RLS Log Surveys of the 100-FR-1 Operable Unit $\ldots \ldots \ldots \ldots \ldots \ldots \ldots \ldots \ldots \ldots$

6. Summary of Maximum Radionuclide Depths from RLS Log Surveys, and the Estimated Depths from the Description of Work for Vadose Drilling

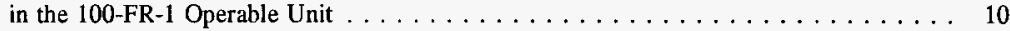


WHC-SD-EN-TI-258, Rev 0

\section{SPECTRAL GAMMA-RAY LOGGING REPORT FOR THE SIX NEW CHARACTERIZATION BOREHOLES IN THE 100-FR-1 OPERABLE UNIT}

\subsection{INTRODUCTION}

Six characterization boreholes were drilled and abandoned in February and March of 1993 in and for the 100-FR-1 Operable Unit (Figure 1). These boreholes are 116-F-1A; 116-F-2, 116-F-9C, and 116-F-14; 116-F-4, and 116-F-6 shown on Figures 2 - 4, respectively. All boreholes were logged with the Radionuclide Logging System (RLS) per the 100-FR-1 Operable Unit work plan. The data were analyzed and the summary reports prepared and passed to the client at that time. The summary reports consist of the borehole and survey particulars, plots of the analyzed data and a short written summary of the results (Appendix A). Cesium, cobalt, and europium were detected in most of the boreholes in minor quantities (less than $100 \mathrm{pCi} / \mathrm{g}$ ), while cesium was detected at a depth of $2.5 \mathrm{ft}$ in one borehole $(116-\mathrm{F}-4)$ at $435 \mathrm{pCi} / \mathrm{g}$ and in fairly high amounts, peaking at $2280 \mathrm{pCi} / \mathrm{g}$ at $10.5 \mathrm{ft}$. Europium peaks of $143 \mathrm{pCi} / \mathrm{g}$ at $32 \mathrm{ft}, 169 \mathrm{pCi} / \mathrm{g}$ at $23 \mathrm{ft}$, and $730 \mathrm{pCi} / \mathrm{g}$ at $23.5 \mathrm{ft}$ were measured in boreholes $116-\mathrm{F}-2,116-\mathrm{F}-6$, and $116-\mathrm{F}-14$, respectively.

The contents of this report are limited to the description of the survey results for each borehole logged. A description and details of the RLS system and how it worked in this project and the limitations to radioelement analysis are contained in Appendix B. Readers unfamiliar with this sophisticated, state-of-the-art logging system are referred to this appendix and urged to review it for pertinent information to familiarize themselves with its detailed capabilities and data use limitations.

Details of equipment configuration, calibration, logging procedures, casing and water correction factors, spectral analysis software, and data management have been excluded from this report. The details of these topics are described in the papers cited.

\subsection{SITE SETTING}

The 100-FR-1 Operable Unit is located adjacent to the Columbia River in the northern part of the Hanford Site. The gamma-emitting wastes of the 100-FR-1 Operable Unit are unlike any others

found in the 100 Areas. They were mostly imported from the 200 and 300 Areas of the Hanford Site to be used in experiments with livestock. The "animal farms" of the 100-FR-1 were hosts to a variety of activities and contamination. To examine the extent of the contamination, boreholes were drilled and sampled. These holes (shown in Figures 2 through 4) were subsequently logged by with RLS to detail the extent of gamma-ray-emitting particles in the subsurface. This report details information from the data for each borehole. 
WHC-SD-EN-TI-258, Rev 0

Figure 1. Operable Unit Location Map.

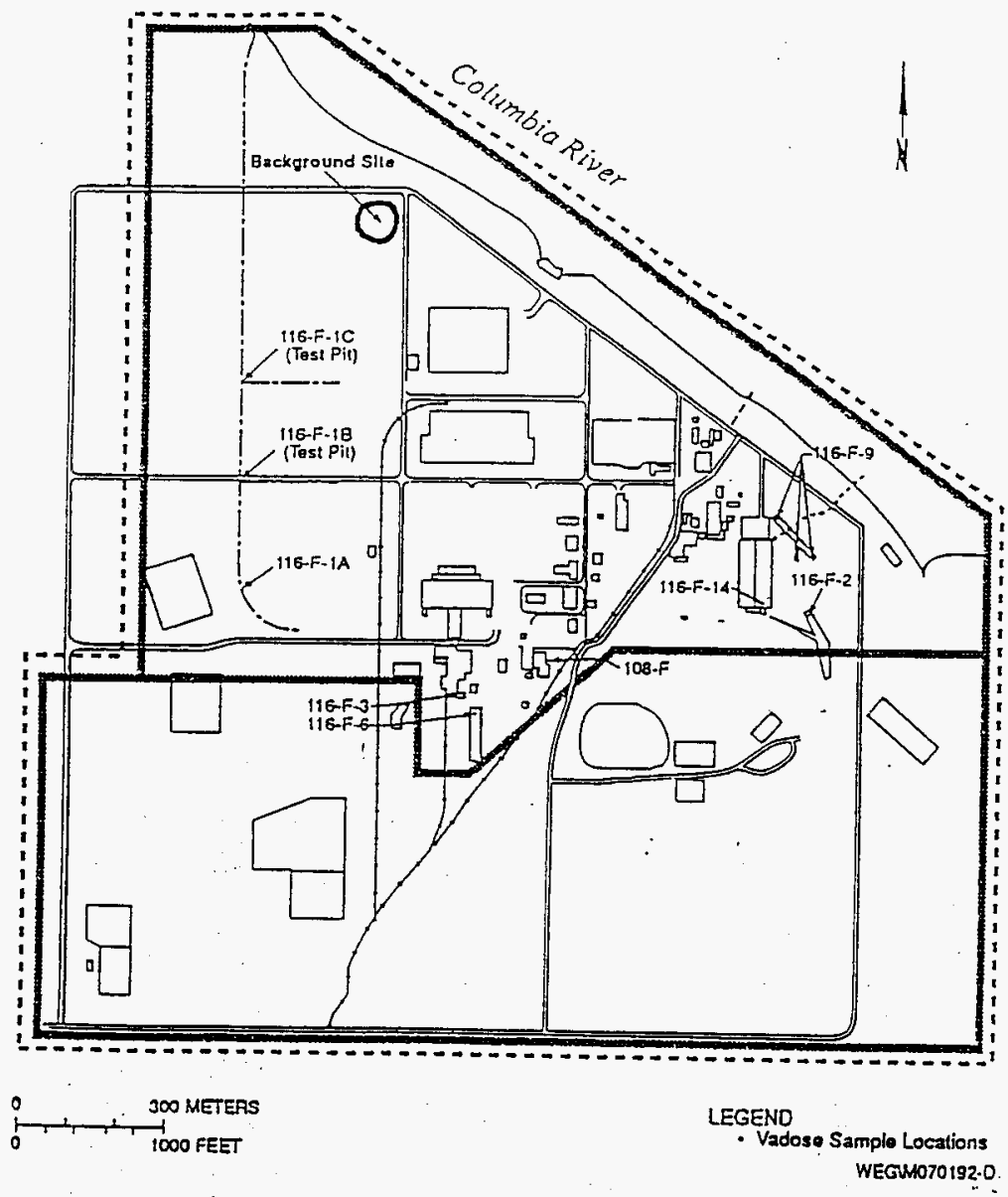


WHC-SD-EN-TI-258, Rev 0

Figure 2. Location of Boreholes (116-F-1A).

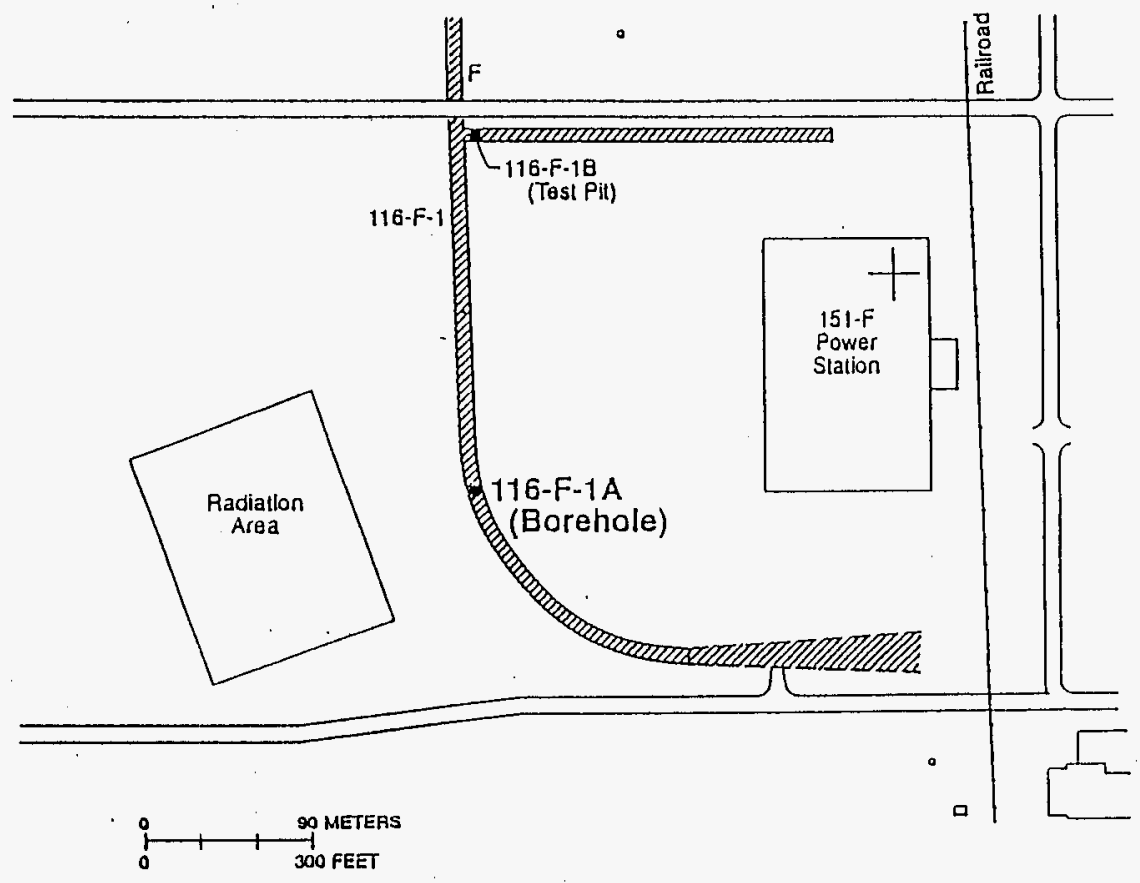

LEGEND

- Soil Sampling Location 
WHC-SD-EN-TI-258, Rev 0

Figure 3. Location of Boreholes (116-F-2, 116-F-9, \& 116-F-9C).

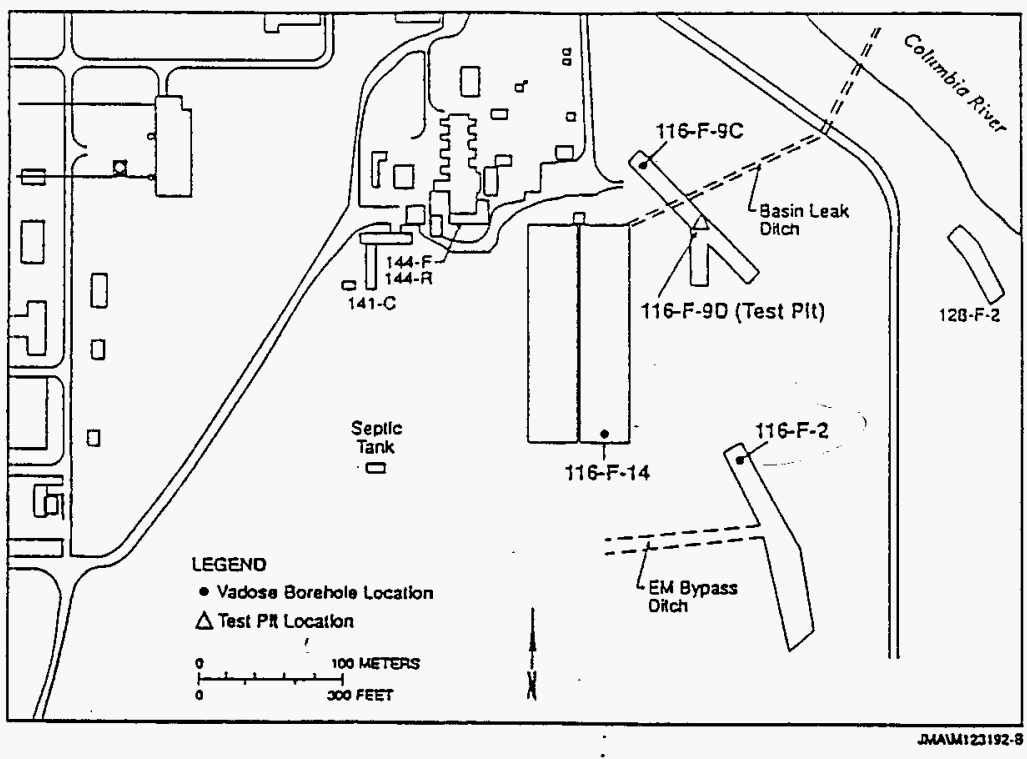


WHC-SD-EN-TI-258, Rev 0

Figure 4. Location of Boreholes (11-F-4 \& 116-F-6) .




WHC-SD-EN-TI-258, Rev 0

\subsection{GEOLOGY}

The Hanford Site lies within the Pasco Basin, a regional, structural and topographic, sediment-filled basin. The sediments for the Pasco Basin are underlain by Miocene-age basalt. The sediments overlying the basalt are from oldest to youngest as follows: Miocene-Pliocene Ringold Formation, post-Ringold pre-Hanford sediments, glacio-fluvial deposits of the Hanford formation, and surficial, Holocene eolian and fluvial sediments.

The vadose zone beneath the 100-F Area comprises primarily unconsolidated sediments of the Hanford formation. This highly permeable unit is composed of mainly cobbles, boulders, gravel, and course sands. Each borehole lies in, or adjacent to, a known area of contamination. It is expected that horizontal migration of contamination in the vadose zone would be minimal or absent. The boreholes logged are expected to give a good estimate of the contamination at that point. It would be unrealistic to try to correlate the contamination of a logged borehole with that of another, given the distances between the boreholes.

\subsection{THE SURVEY DATA}

Appendix A contains all the RLS data and results. The cover page for each well, entitled "RLS Spectral Gamma-Ray Borehole Survey Log Header," summarize the borehole and survey information. Tables 1 through 5 below also summarize the data. Plots of the total gamma-ray counts per second (Total Gamma) along with the calculated man-made isotope concentrations are presented on the page following the header. The "Total Gamma" is the count rate for all gamma rays detected by the RLS detector, with no discrimination of gamma-ray energy. The Total Gamma is equivalent to the gross gamma-ray log commonly used in the past at Hanford.

The plots of radionuclide-activity response versus depth shown in Appendix A are followed with notes and a summary. On the plots of Appendix A, a uniform depth scale of $20 \mathrm{ft}$ per inch, and a radionuclide-concentration scale of $40 \mathrm{pCi} / \mathrm{g}$ per inch are used. The experimental uncertainties in the computed radionuclide activities are not presented on the data plots at this time.

The decay activity for the natural radionuclides, potassium, uranium, and thorium, have been computed through the normal spectral analysis of the data reduction program and are presented, with the Total Gamma, on the page following the plots of the other data.

Long-count, stationary measurements of at least 300 seconds (shown as short bars in the plotted data) were recorded at some depth points (stations) in all holes to verify the validity of the data acquired with the 80-seconds-per-half-ft survey. Both the long and 80 -second measurements were acquired at essentially some given common depth. The extended acquisition time did not identify additional radionuclides in any of these wells or characterization holes. 
WHC-SD-EN-TI-258, Rev 0

Table 1. Summary of Maximum Radionuclide Depths from RLS Log Surveys of the 100-FR-1 Operable Unit.

\begin{tabular}{|c|c|c|c|c|c|c|}
\hline $\begin{array}{l}\text { Borehole } \\
\text { ID }\end{array}$ & $\begin{array}{l}\text { Survey } \\
\text { Date' }\end{array}$ & $\begin{array}{l}\text { Survey } \\
\text { Depth }^{2}\end{array}$ & $\begin{array}{c}\text { Cesium-137 } \\
\text { Depth }^{3}\end{array}$ & $\begin{array}{l}\text { Cobalt }-60 \\
\text { Depth }^{3}\end{array}$ & $\begin{array}{c}\text { Europium-152 } \\
\text { Depth }^{3}\end{array}$ & $\begin{array}{c}\text { Europium-154 } \\
\text { Depth }^{3}\end{array}$ \\
\hline $116-F-1 A$ & $2 / 10 / 93$ & $16.5^{\prime}$ & $5.5^{\prime}$ & 5 , & $5.5^{\prime}$ & $6.5^{\prime}$ \\
\hline $116-F-4$ & $3 / 02 / 93$ & $25^{\prime}$ & 22 ' & not detected & $14^{\prime}$ & $13.5^{\prime}$ \\
\hline $116-F-9 C$ & $2 / 17 / 93$ & $26^{\prime}$ & $17.5^{\prime}$ & not detected & not detected & not detected \\
\hline $116-F-14$ & $3 / 04 / 93$ & $23.5^{\prime}$ & $23.5^{\prime}$ & $9.5^{\prime}$ & $13^{\prime}$ & $12.5^{\prime}$ \\
\hline
\end{tabular}

'Date survey was completed

${ }^{2}$ Maximum survey depth

${ }^{3}$ Maximum depth where radionuclide was identified

Table 2. Summary of Cesium-137 detected from RLS Log Surveys of the 100-FR-1 Operable Unit.

\begin{tabular}{|c|c|c|c|c|}
\hline $\begin{array}{c}\text { Borehole } \\
\text { ID }\end{array}$ & $\begin{array}{l}\text { Survey } \\
\text { Depth }^{1}\end{array}$ & $\begin{array}{c}\text { Cesium-137 } \\
\text { Interval(s) } \\
\text { (feet) }\end{array}$ & $\begin{array}{c}\text { Depth of } \\
\text { Maximum } \\
\text { Activity }\end{array}$ & $\begin{array}{l}\text { Maximum } \\
\text { Activity } \\
(\mathrm{pCi} / \mathrm{g})^{3}\end{array}$ \\
\hline 116-F-1A & $16.5^{\prime}$ & $1-5.5$ & 3.5 & $4 \mathrm{pCi} / \mathrm{g}$ \\
\hline 116-F-2 & $32^{\prime}$ & $7-32^{\prime}$ & $14.5^{\circ}$ & 19 \\
\hline $116-F-4$ & $25^{\prime}$ & $0-22^{\prime}$ & $2.5^{\prime}, 10.5^{\prime}$ & 435,2280 \\
\hline $116-F-9 C$ & $26^{\prime}$ & $16.5-17.5$ & $17^{\prime}$ & 0.3 \\
\hline $116-\mathrm{F}-6$ & $23^{\prime}$ & $5-15^{\prime}$ & $6.5^{\prime}$ & 74 \\
\hline $116-F-14$ & $23.5^{\prime}$ & $4.5-23.5^{\prime}$ & $7.5^{\prime}$ & 6.5 \\
\hline
\end{tabular}

${ }^{1}$ Maximum survey depth

${ }^{2}$ Depth intervals where Cesium was identified

${ }^{3}$ Pico-Curies per gram 
WHC-SD-EN-TI-258, Rev 0

Table 3. Summary of Cobalt-60 detected from RLS $\mathrm{Log}$ Surveys of the 100-FR-1 Operable Unit.

\begin{tabular}{|c|c|c|c|c|}
\hline $\begin{array}{l}\text { Borehole } \\
\text { ID }\end{array}$ & $\begin{array}{l}\text { Survey } \\
\text { Depth }^{1}\end{array}$ & $\begin{array}{c}\text { Cobalt-60 } \\
\text { Interval(s) } \\
\text { (feet) }\end{array}$ & $\begin{array}{l}\text { Depth of } \\
\text { Maximum } \\
\text { Activity }\end{array}$ & $\begin{array}{l}\text { Maximum } \\
\text { Activity } \\
(\mathrm{pCi} / \mathrm{g})^{3}\end{array}$ \\
\hline 116-F-1A & $16.5^{\prime}$ & $1-5$ & $3.5^{\prime}$ & $4 \mathrm{pCi} / \mathrm{g}$ \\
\hline 116-F-2 & $32^{\prime}$ & $6-21.5$ & $14.5^{\prime}$ & 6.3 \\
\hline $116-\mathrm{F}-4$ & $25^{\prime}$ & none detected & - & - \\
\hline 116-F-9C & $26^{\prime}$ & none detected & - & - \\
\hline $116-F-6$ & $23^{\prime}$ & $4.5-10^{\prime}$ & $6.5^{\prime}$ & 18 \\
\hline $116-\mathrm{F}-14$ & $23.5^{\prime}$ & $0.5-9.5$ & $4^{\circ}$ & 31 \\
\hline
\end{tabular}

${ }^{1}$ Maximum survey depth

${ }^{2}$ Depth intervals where Cobalt was identified

${ }^{3}$ Pico-Curies per gram

Table 4. Summary of Europium-152 Detected from RLS Log Surveys of the 100-FR-1 Operable Unit.

\begin{tabular}{|c|c|c|c|c|}
\hline $\begin{array}{c}\text { Borehole } \\
\text { ID }\end{array}$ & $\begin{array}{c}\text { Survey } \\
\text { Depth }^{1}\end{array}$ & $\begin{array}{c}\text { Europium-152 } \\
\text { Interval(s) } \\
\text { (feet) }\end{array}$ & $\begin{array}{c}\text { Depth of } \\
\text { Maximum } \\
\text { Activity }\end{array}$ & $\begin{array}{c}\text { Maximum } \\
\text { Activity } \\
(\mathrm{pCi} / \mathrm{g})^{3}\end{array}$ \\
\hline \hline $116-\mathrm{F}-1 \mathrm{~A}$ & $16.5^{\prime}$ & $1-5.5^{\prime}$ & $3.5^{\prime}$ & $20 \mathrm{pCi} / \mathrm{g}$ \\
\hline $116-\mathrm{F}-2$ & $32^{\prime}$ & $1.5-30^{\prime}$ & $10.5^{\prime}$ & 143 \\
\hline $116-\mathrm{F}-4$ & $25^{\prime}$ & $24^{\prime}, 6^{\prime}-14^{\prime}$ & $2.5^{\prime}, 1^{\prime}$ & 5,20 \\
\hline $116-\mathrm{F}-9 \mathrm{C}$ & $26^{\prime}$ & none detected & - & - \\
\hline $116-\mathrm{F}-6$ & $23^{\prime}$ & $4-16^{\prime}$ & $6.5^{\prime}$ & 169 \\
\hline $116-\mathrm{F}-14$ & $23.5^{\prime}$ & $0.5-13^{\prime}$ & $4^{\prime}$ & 730 \\
\hline
\end{tabular}

${ }^{1}$ Maximum survey depth

${ }^{2}$ Depth intervals where Europium-152 was identified

${ }^{3}$ Pico-Curies per gram 
WHC-SD-EN-TI-258, Rev 0

Table 5. Summary of Europium-154 detected from RIS Log Surveys of the 100-FR-1 Operable Unit.

\begin{tabular}{|c|c|c|c|c||}
\hline $\begin{array}{c}\text { Borehole } \\
\text { ID }\end{array}$ & $\begin{array}{c}\text { Survey } \\
\text { Depth' }\end{array}$ & $\begin{array}{c}\text { Europium-154 } \\
\text { Interval(s) } \\
\text { (feet) }\end{array}$ & $\begin{array}{c}\text { Depth of } \\
\text { Maximum } \\
\text { Activity }\end{array}$ & $\begin{array}{c}\text { Maximum } \\
\text { Activity } \\
\left(\mathrm{pCi}^{2} /\right)^{3}\end{array}$ \\
\hline \hline $116-\mathrm{F}-1 \mathrm{~A}$ & $16.5^{\prime}$ & $1-6.5^{\prime}$ & $3.5^{\prime}$ & $3 \mathrm{pCi} / \mathrm{g}$ \\
\hline $116-\mathrm{F}-2$ & $32^{\prime}$ & $6-20.5^{\prime}$ & $14^{\prime}$ & 13.6 \\
\hline $116-\mathrm{F}-4$ & $25^{\prime}$ & $9-13.5^{\prime}$ & $9.5^{\prime}$ & 2 \\
\hline $116-\mathrm{F}-9 \mathrm{C}$ & $26^{\prime}$ & none detected & - & - \\
\hline $116-\mathrm{F}-6$ & $23^{\prime}$ & $4.5-10^{\prime}$ & $6^{\prime}$ & 20 \\
\hline $116-\mathrm{F}-14$ & $23.5^{\prime}$ & $0-12.5^{\prime}$ & $4^{\prime}$ & 92 \\
\hline
\end{tabular}

${ }^{1}$ Maximum survey depth

${ }^{2}$ Depth intervals where Europium-154 was identified

${ }^{3}$ Pico-Curies per gram

\subsection{CONCLUSIONS}

The 100-FR-1 Area hosts contamination unlike that of the other 100 Areas. However, the gamma-emitting wastes in the subsurface are similar to those of the 200 Area wastes.

The Description of Work (Ayers 1993) details estimates on depth to groundwater and expected waste depth. Table 6 presents the estimates from the Description of Work alongside the results of the RLS Spectral Gamma Analysis. Most of the estimates were very close to the RLS results, with the exception of borehole 116-F-2. At 116-F-2, the detected gamma rays from contamination were as deep as $32 \mathrm{ft}$ (the maximum depth of the survey). The estimates did not predict this result.

See the General Notes of the Borehole Survey Reports in Appendix A for more detailed information on individual boreholes. 
WHC-SD-EN-TI-258, Rev 0

Table 6. Summary of Maximum Radionuclide Depths from

RLS Log Surveys and the Estimated Depths from the Description of Work for Vadose Drilling in the 100-FR-1 Operable Unit.

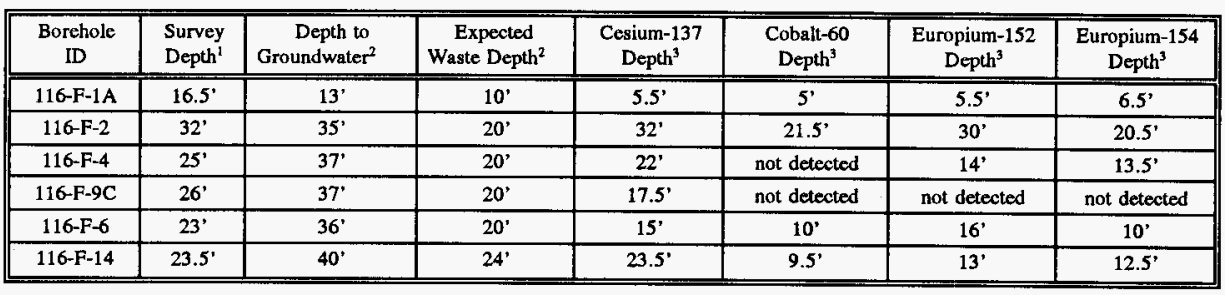

${ }^{1}$ Maximum survey depth

${ }^{2}$ As estimated in the Description of Work: WHC-SD-EN-AP-091, Rev. 1

${ }^{3}$ Maximum depth where radionuclide was identified 
WHC-SD-EN-TI-258, Rev 0

\subsection{FUTURE CONSIDERATIONS}

The 100-FR-1 Operable Unit historically received large quantities of strontium-90. This radioelement was used extensively at the "sheep barn" in experiments. Strontium decays by beta emission and does not release gamma radiation. However, the beta particle released is of very high energy and can excite surrounding elements to emit photon (gamma-ray) radiation that can be identified by the HPGe detector. This type of radiation is called "bremsstrahlung" radiation. A method to obtain estimates of the concentrations of strontium-90 is under consideration.

\subsection{REFERENCES}

Ayres, J. M. 1993, Description of Work for Vadose Drilling in the 100-FR-1 Operable Unit, WHC-SD-EN-AP-091, Rev 1, Westinghouse Hanford Company, Richland, Washington.

Brodeur, J. R., Koizumi, C. J., Ulbricht, W. H. Jr., and Price, R. K., 1991, Calibration of a HighResolution Passive Gamma-Ray Logging System for Nuclear Waste Assessment, WHC-SA-1175-FP, Westinghouse Hanford Company, Richland, Washington.

Brodeur, J. R, Koizumi, C. J. Price, R. K. and Wilson, R. D., 1992, Gamma-Ray Logging results for the 200 Aggregate Area Management Study, WHC-SD-EN-TI-021, Westinghouse Hanford Company, Richland, Washington.

Koizumi, C. J., Brodeur, J. R., Ulbricht, W. H. Jr., and Price, R. K., 1991, Calibration of the RLS HPGe Spectral Gamma-Ray Logging System, WHC-EP-0464, Westinghouse Hanford Company, Richland, Washington.

Koizumi, C. J., Price, R. K., and Wilson, R. D., 1992, Calibration of the RLS System for 200 Aggregate Area Management Study Screening Measurements, WHC-SD-EN-TRP-001, Westinghouse Hanford Company, Richland, Washington. 
WHC-SD-EN-TI-258, Rev 0

APPENDIX A

RLS SURVEY DATA AND SPECTRAL GAMMA PLOTS

A-1 
WHC-SD-EN-TI-258, Rev 0

This page intentionally left blank.

A-2 
WHC-SD-EN-TI-258, Rev 0

\section{Westinghouse Hanford Company \\ RLS Spectral Gamma-Ray Borehole Survey Log Header}

Project: $100 \mathrm{FR}-1$

$\begin{array}{lll}\begin{array}{l}\text { Borehole } \\ \text { Coordinates } \\ \text { Elevation }\end{array} & \frac{116-F-1 A}{N A} N-N A & \text { Feet (Hanford } 100 \text { Area) } \\ \text { NA } & \text { ft } & \text { Top of casing (Hanford } 100 \text { Area) }\end{array}$

Borehole Environment Information

\begin{tabular}{|c|c|c|c|}
\hline \hline $\begin{array}{c}\text { Borehole liquid depth none (ft) from zero (0.0) depth reference of log } \\
\text { (in.) }\end{array}$ & $\begin{array}{c}\text { Casing thickness } \\
\text { (in.) }\end{array}$ & $\begin{array}{c}\text { Top depth } \\
(\mathrm{ft})\end{array}$ & $\begin{array}{c}\text { Base depth } \\
\text { (ft) }\end{array}$ \\
\hline \hline 8 & 0.322 & 0 & 20 \\
\hline & & & \\
\hline
\end{tabular}

RLS Passive Spectral Gamma Survey Information

\begin{tabular}{|c|c|c|c|c|}
\hline \multicolumn{5}{|c|}{$\begin{array}{l}\text { Logging Engineers } \frac{\text { R. V. Cram }}{\text { Log depth reference at zero }(0.0)} \frac{\text { S. E. Kos }}{\text { depth is ground leve }}\end{array}$} \\
\hline Log Date & $\begin{array}{l}\text { Archive } \\
\text { file names }\end{array}$ & Log mode speed & $\begin{array}{c}\text { Depth intervat } \\
\text { Top Base }\end{array}$ & ft) \\
\hline Feb 10, 1993 & H116F01A\A329 & MSA $80 \mathrm{sec}$ RT & 16.5 & 0.5 \\
\hline Feb 10, 1993 & H116F0IA\A329 & Station $300 \mathrm{sec}$ & $3.8,16.5$ & \\
\hline
\end{tabular}

Calibration and Analysis Information

RLS CaTibration Date: Nov. 21, 199?

Calibration Report: WHC-SD-EN-TRP-001

Analyst Names: W. F. Nicaise R. K. Price

Analys is Date: Jan.15,1993

R. K. Price

Analysis Notes:

Radionuclides Identified: Cs-137, Co-60, Eu-152, Eu- 154 
WHC-SD-EN-TI-258, Rev 0

RLS Spectral Gamma-Ray Borehole Survey

Project: $100 \mathrm{FR}-1$

Borehole: $116-F-1 \mathrm{~A}$
Log Date: Feb 10, 1993 Anal. Date: Mar 03, 1993

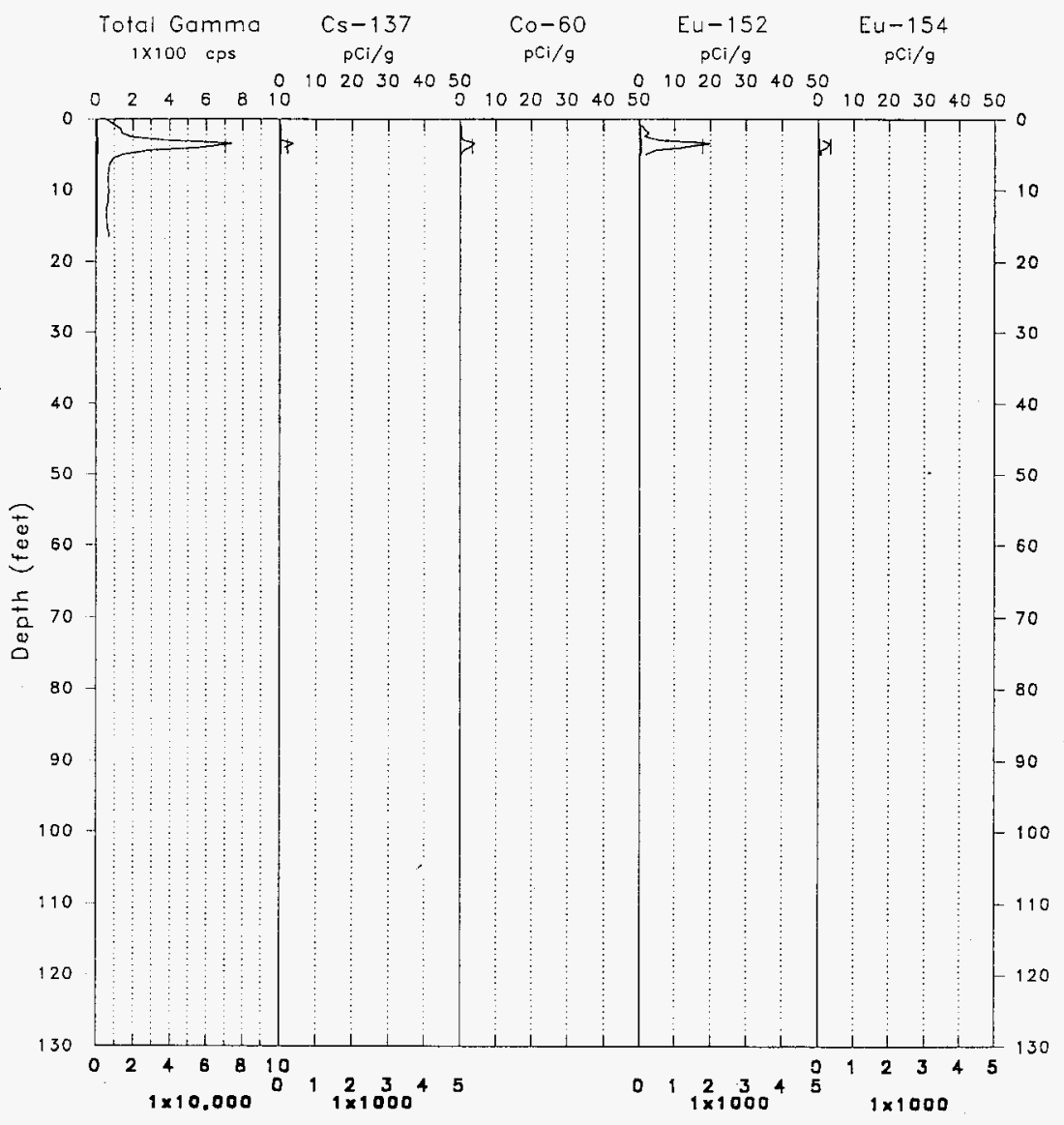


WHC-SD-EN-TI-258, Rev 0

\begin{abstract}
RLS Spectral Gamma-Ray Borehole Survey
Project: 100 FR -1

Borehole : $116-F-1 \mathrm{~A}$ Log Date : Feb 10, 1993 Anal Date: Mar 03, 1993
\end{abstract}

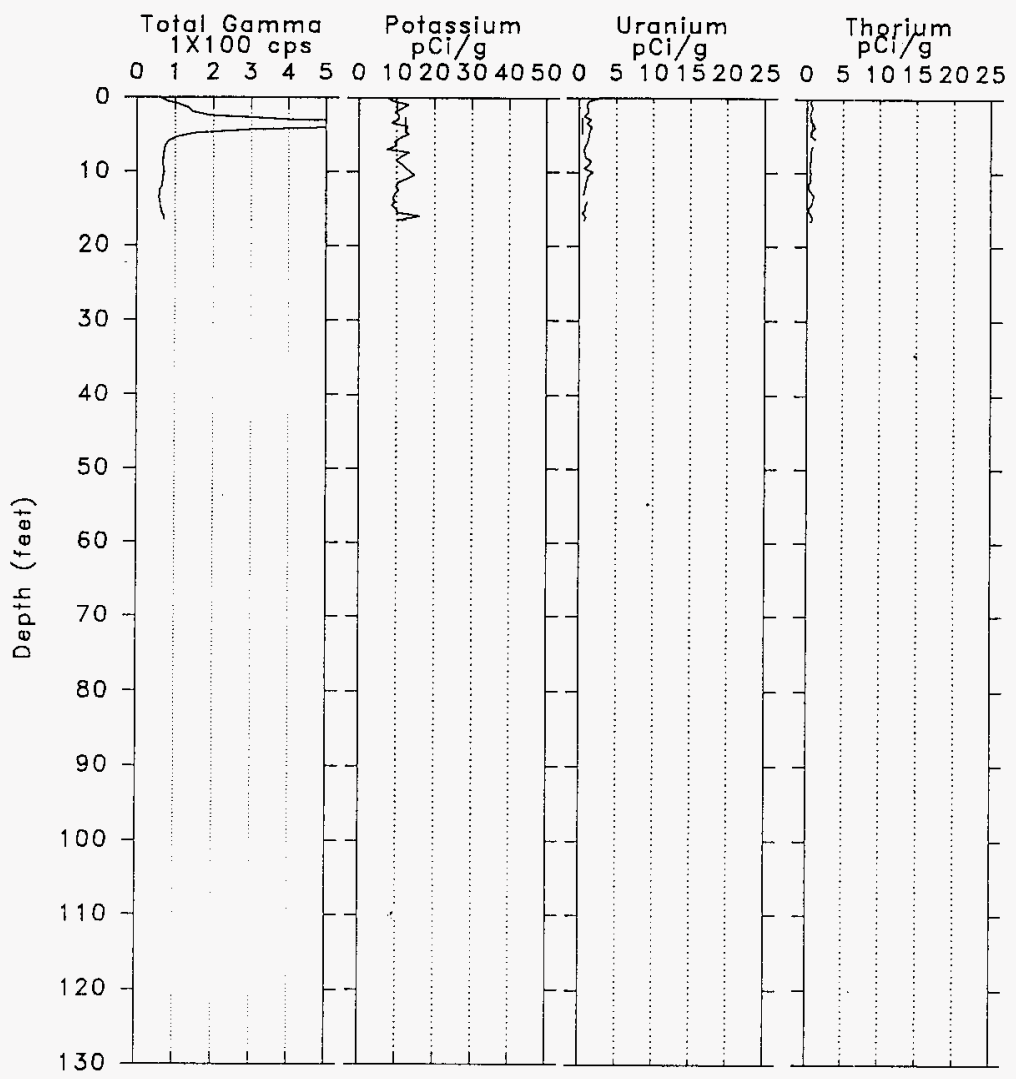


WHC-SD-EN-TI-258, Rev 0

\section{RLS Borehole Survey Report}

Borehole: 116-F-1A

$\begin{array}{llll}\text { Casing } & \text { Depth: } 20^{\prime} & \text { Size: } 8^{\prime \prime} & \text { Thickness: } 0.322^{\prime \prime} \\ \text { Water } & \text { Depth: 18.2' } & & \\ \text { Survey } & \text { Depth: } 0-16.5^{\prime} & \text { Date: } 02 / 10 / 93 & \end{array}$

\section{General Notes:}

The well was monitored from 0 to 16.5 feet, at intervals of 0.5 feet, for real time counting intervals of 80 seconds. In addition the well was monitored at the fixed depths of 3.8 feet and 16.5 feet, for real time counting intervals of 300 seconds. The man-made radionuclides Cs-137, Co-60, Eu-152, and Eu-154 were observed, as well as the naturally occurring radionuclides potassium, uranium, and thorium. The man-made radionuclides were observed in a depth region of from one to 6.5 feet, and they all peaked in activity at approximately 3.5 feet. These man-made radionuclide activities coincide with and account for the peak of the total gamma ray count rate observed at 3.5 feet. These data are shown on the first plot, and are described in the text below.

The naturally occurring radionuclides are observed at activities which are normal for Hanford soils and are shown on the second plot.

Man-made Radionuclides:

Cesium (Cs-137) was detected from one to 5.5 feet. The maximum calculated activity of $4 \mathrm{pCi} / \mathrm{g}$ occurs at 3.5 feet.

Cobait (Co-60) was detected from one to five feet. The maximum calculated activity of $4 \mathrm{pCi} / \mathrm{g}$ occurs at 3.5 feet.

Europium (Eu-152) was detected from one to 5.5 feet. The maximum calculated activity of $20 \mathrm{pCi} / \mathrm{g}$ occurs at 3.5 feet.

Europium (Eu-154) was detected from one to 6.5 feet. The maximum calculated activity of $3 \mathrm{pCi} / \mathrm{g}$ occurs at 3.5 feet. 


\section{Westinghouse Hanford Company RLS Spectral Gamma-Ray Borehole Survey Log Header}

Project: $100 \mathrm{FR}-1$

Borehole
Coordinates
Elevation

Borehole Environment Information

\begin{tabular}{|c|c|c|c|}
\hline Borehole liquid depth none (ft) from zero (0.0) depth reference of log \\
\hline \hline $\begin{array}{c}\text { Casing size } \\
(\text { in.) }\end{array}$ & $\begin{array}{c}\text { Casing thickness } \\
\text { (in.) }\end{array}$ & $\begin{array}{c}\text { Top depth } \\
(\mathrm{ft})\end{array}$ & $\begin{array}{c}\text { Base depth } \\
(\mathrm{ft})\end{array}$ \\
\hline \hline 8 & 0.5 & 0 & 25.8 \\
\hline 6 & 0.45 & 25.2 & 33.0 \\
\hline & & & \\
\hline
\end{tabular}

RLS Passive Spectrai Gamma Survey Information

\begin{tabular}{|c|c|c|c|c|c|}
\hline \multicolumn{6}{|c|}{$\begin{array}{l}\text { Logging Engineers } \frac{R . V . \text { Cram }}{\text { Log depth reference at zero }(0.0)} \frac{\text { S. E. Kos }}{\text { depth is ground level }}\end{array}$} \\
\hline Log Date & $\begin{array}{l}\text { Archive } \\
\text { file names }\end{array}$ & Log mode speed & $\begin{array}{l}\text { Deptl } \\
\text { Top } \\
\end{array}$ & $\begin{array}{l}\text { interva } \\
\text { Base }\end{array}$ & $\begin{array}{l}(\mathrm{ft}) \\
\text { Incr }\end{array}$ \\
\hline Feb 04,1993 & $\mathrm{H} 116 \mathrm{~F} 02 \backslash \mathrm{A} 324$ & $80 \mathrm{sec}$ RT & 0 & 25 & 0.5 \\
\hline Feb 04,1993 & $\mathrm{H} 116 \mathrm{FO} 2 \backslash \mathrm{A} 324$ & $80 \mathrm{sec}$ RT & 25 & 31 & 0.5 \\
\hline Feb 04,1993 & $\mathrm{H}] 16 \mathrm{~F} 02 \backslash \mathrm{A} 324$ & Station $300 \mathrm{sec}$ & & $25.1^{\prime}$ & \\
\hline
\end{tabular}

Asterove-Stop.Acquire

A'T: Real time

Calibration and Analysis Information

RLS Cal jbration Date: Nov. 21, 1991

Calibration Report: WHC-SD-EN-TRP-001

Analyst Names: W. F. Nicaise R. K. Price

Analys is Date: $\underline{\text { Jan. 15, } 1993}$

Analysis Notes: Natural Uranium activity slightly elevated near surface Radionuclides Identified: $[\mathrm{Cs}-137, \mathrm{C} 0-60$, Eu-152, Eu-154 
RLS Spectral Gamma-Ray Borehole Survey

Project: $100 \mathrm{FR}-1$

Borehole: $116-F-2$
Log Date: Feb 04, 1993 Anal. Date: Feb 23, 1993

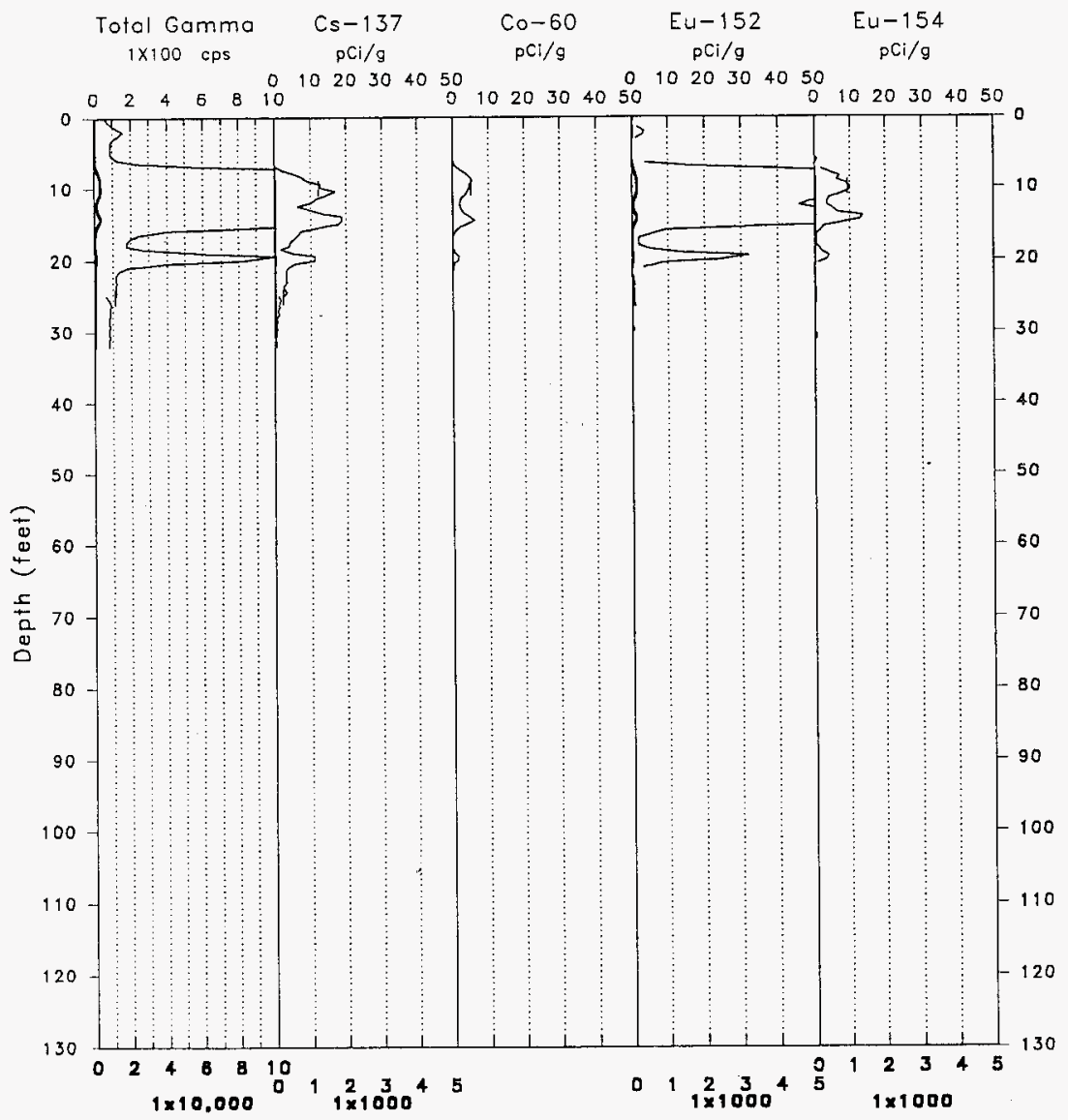


WHC-SD-EN-TI-258, Rev 0

RLS Spectral Gamma-Ray Borehole Survey

Project: $100 \mathrm{FR}-1$

Borehole : 116-F-2
Log Date : Feb 04, 1993 Anal Date: Feb 23, 1993

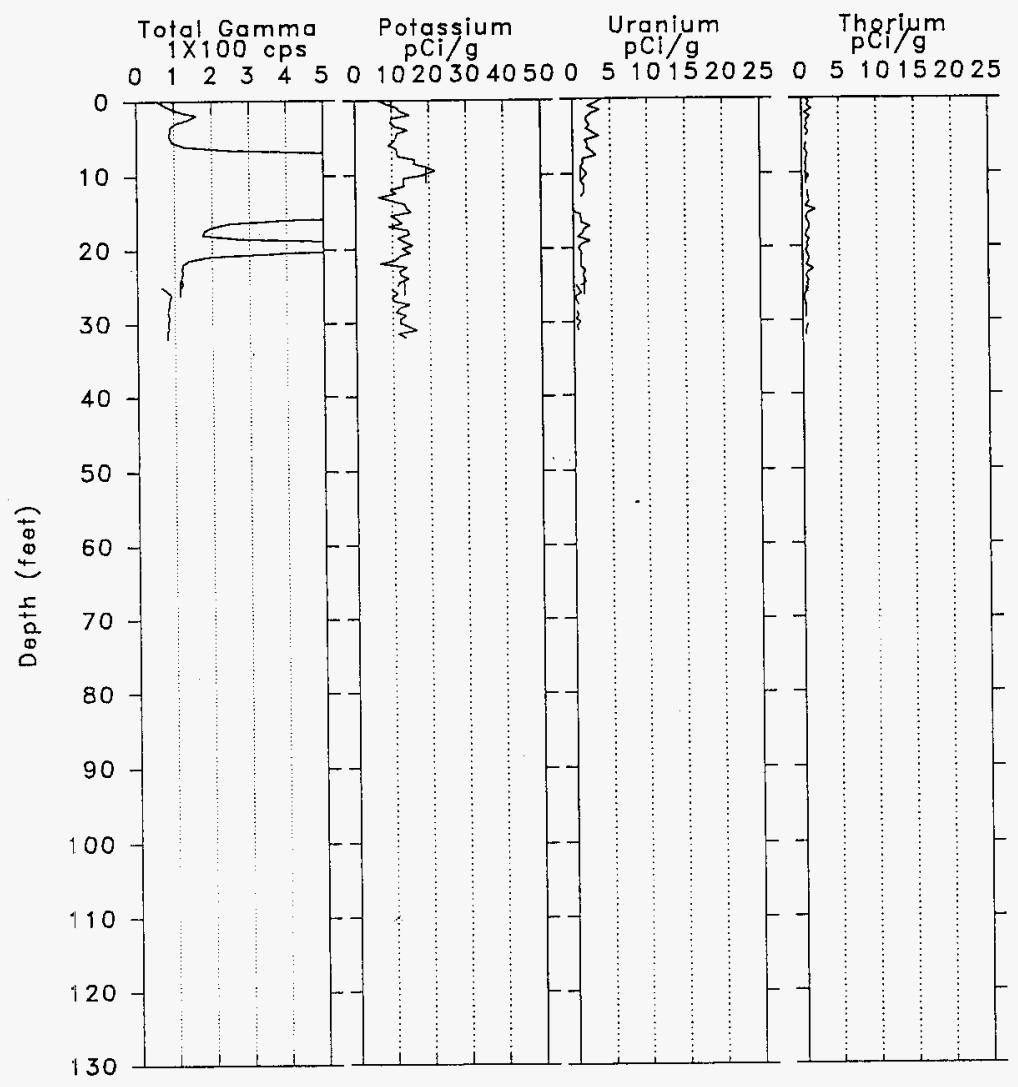




\section{WHC-SD-EN-TI-258, Rev 0}

\section{RLS Borehole Survey Report}

Borehole: $116-F-2$

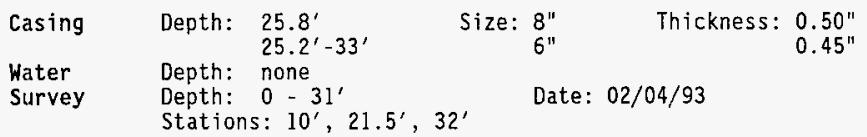

\section{General Notes:}

The well was monitored from 0 to 32 feet at intervals of 0.5 feet for real counting times of 80 seconds. The man-made radionuclides Cs-137, Co-60, Eu152, and Eu-154 were observed as well as the naturally occurring radionuclides potassium, uranium, and thorium. The Cesium is present from about five feet to 32 feet, with a broad activity peak from about 10 to 20 feet. The cobalt is found to be present from about five feet to 22 feet, with a broad activity peak from eight to 18 feet. This activity was less intense than that of the Cesium. Europium-152 is present from about five feet to 23 feet with a broad activity peak from five feet to 18 feet, and another peak of lower intensity at: 20 feet. This activity is the most intense of all the radionuclides found. Europium-154 is present from about five to 20 feet with a broad activity peak from five to 18 feet and a secondary peak at 20 feet. The total gamma count rate was dominated by and matched the Eu-152 activity profile. These man-made radionuclide activities are shown on the first plot, and are described briefly and more quantitatively in the following section.

The natural radionuclides are present throughout the depth of the well, generaliy at activity levels which are normal for Hanford soils. The single exception is uranium which is present at slightly elevated levels for the first eight feet of the well depth. These activities are shown on the second plot. A check of the barometric pressure records from the PNL weather station reveals that the pressure was high, i. e. $>29.5 \mathrm{in} . \mathrm{Hg}$, for two days previous to the logging date of 2/4/93. The pressure began to drop at about 9:00 a.m. on the logging date and ended the day at $29.3 \mathrm{in}$. Hg. Such barometric conditions are favorable to the plating out on the inner surface of the well casing of Radon which can contribute to an elevated uranium count rate.

Man-made Radionuciides:

Cesium (Cs-137) was detected from seven to the maximum surveyed depth of 32 feet. The maximum activity of $19 \mathrm{pCi} / \mathrm{g}$ occurred at 14.5 feet.

Cobait $(\mathrm{Co}-60)$ was detected from six to 21.5 feet. The maximum activity of $6.3 \mathrm{pCi} / \mathrm{g}$ occurred at 14.5 feet.

Europium (Eu-154) was detected from 1.5 to 30 feet. The maximum activity of $143 \mathrm{pCi} / \mathrm{g}$ occurred at 10.5 feet.

Europium (Eu-152) was detected from six to 20.5 feet. The maximum activity of $13.6 \mathrm{pCi} / \mathrm{g}$ occurred at 14 feet. 
WHC-SD-EN-TI-258, Rev 0

\section{Westinghouse Hanford Company \\ RLS Spectral Gamma-Ray Borehole Survey Log Header}

Project: $100 \mathrm{FR}-1$

\begin{tabular}{|c|c|c|c|}
\hline Bor & -4 & & \\
\hline $\begin{array}{l}\text { Coordinates } \\
\text { Elevation }\end{array}$ & $\overline{N A}^{N} \mathrm{ft}$ & $\begin{aligned} & \overline{N A} W \text { Feet } \\
& \text { Top of casing }\end{aligned}$ & $\begin{array}{l}\text { (Hanford } 100 \text { Area) } \\
\text { (Hanford } 100 \text { Area) }\end{array}$ \\
\hline
\end{tabular}

Borehole Environment Information

\begin{tabular}{|c|c|c|c|}
\hline \begin{tabular}{c} 
Borehole liquid depth none (ft) from zero (0.0) depth reference of log \\
\hline $\begin{array}{c}\text { Casing size } \\
\text { (in.) }\end{array}$
\end{tabular} $\begin{array}{c}\text { Casing thickness } \\
\text { (in.) }\end{array}$ & $\begin{array}{c}\text { Top depth } \\
(\mathrm{ft})\end{array}$ & $\begin{array}{c}\text { Base depth } \\
(\mathrm{ft})\end{array}$ \\
\hline 8 & 0.45 & 0 & 19.4 \\
\hline 6 & 0.28 & 0 & 26.7 \\
\hline
\end{tabular}

RLS Passive Spectral Gamma Survey Information

\begin{tabular}{|c|c|c|c|c|c|}
\hline \multicolumn{6}{|c|}{$\begin{array}{l}\text { Logging Engineers } \frac{R . V . \text { Cram }}{\text { Log depth reference at zero }(0.0)} \frac{S . E \text { depth is gos ground level }}{\text { deth }}\end{array}$} \\
\hline Log Date & $\begin{array}{l}\text { Archive } \\
\text { fjle names }\end{array}$ & Log mode speed & $\begin{array}{l}\text { Depth } \\
\text { Top }\end{array}$ & $\begin{array}{c}\text { interva } \\
\text { Base }\end{array}$ & $\begin{array}{l}(\mathrm{ft}) \\
\text { Incr }\end{array}$ \\
\hline $\begin{array}{l}\text { Feb 25, } 1993 \\
\text { Mar 02, } 1993 \\
\end{array}$ & $\begin{array}{l}\mathrm{H} 116 \mathrm{FO} 04 \backslash \mathrm{A} 334 \\
\mathrm{H} 116 \mathrm{FO4} \backslash \mathrm{A} 337 \\
\end{array}$ & $\begin{array}{lll}\text { MSA } & 80 \text { sec } & R T \\
\text { MSA } & 80 \text { sec } & \text { RT } \\
\end{array}$ & $\begin{array}{l}0 \\
15.5 \\
\end{array}$ & $\begin{array}{l}17.5 \\
24.5 \\
\end{array}$ & $\begin{array}{l}0.5 \\
0.5 \\
\end{array}$ \\
\hline $\begin{array}{ll}\text { Feb 25, } 1993 \\
\text { Mar 02, } 1993\end{array}$ & $\begin{array}{l}\text { HI } 16 F 04 \backslash A 334 \\
\text { H1 } 16 F 04 \backslash A 337\end{array}$ & $\begin{array}{l}\text { Station } 300 \mathrm{sec} \\
\text { Station } 300 \mathrm{sec}\end{array}$ & $2.5^{\prime}$ & $\begin{array}{l}10.5^{\prime} \\
24.9^{\prime}\end{array}$ & \\
\hline & & & & & \\
\hline
\end{tabular}

Calibration and Analysis Information

RLS Calibration Date: Nov. 21, 1991
Calibration Report: WHC-SD-EN-TRP-001
Analyst Names: W. F. Nicaise $\quad$ R. K. Price
Analysis Date: $\frac{\text { Mar. 22, } 1993}{\text { Analysis Notes: Casing Correction exceeds max. from } 15.5^{\prime} \text { to 19.4' }}$
Radionuclides Identified: Co-60, Eu-152, Eu-154




\section{RLS Spectral Gamma-Ray Borehole Survey}

Project: $100 \mathrm{FR}-1$

Borehole: $116-F-4$
Log Date: Feb 25, 1993

Anal. Date: Mar 22, 1993

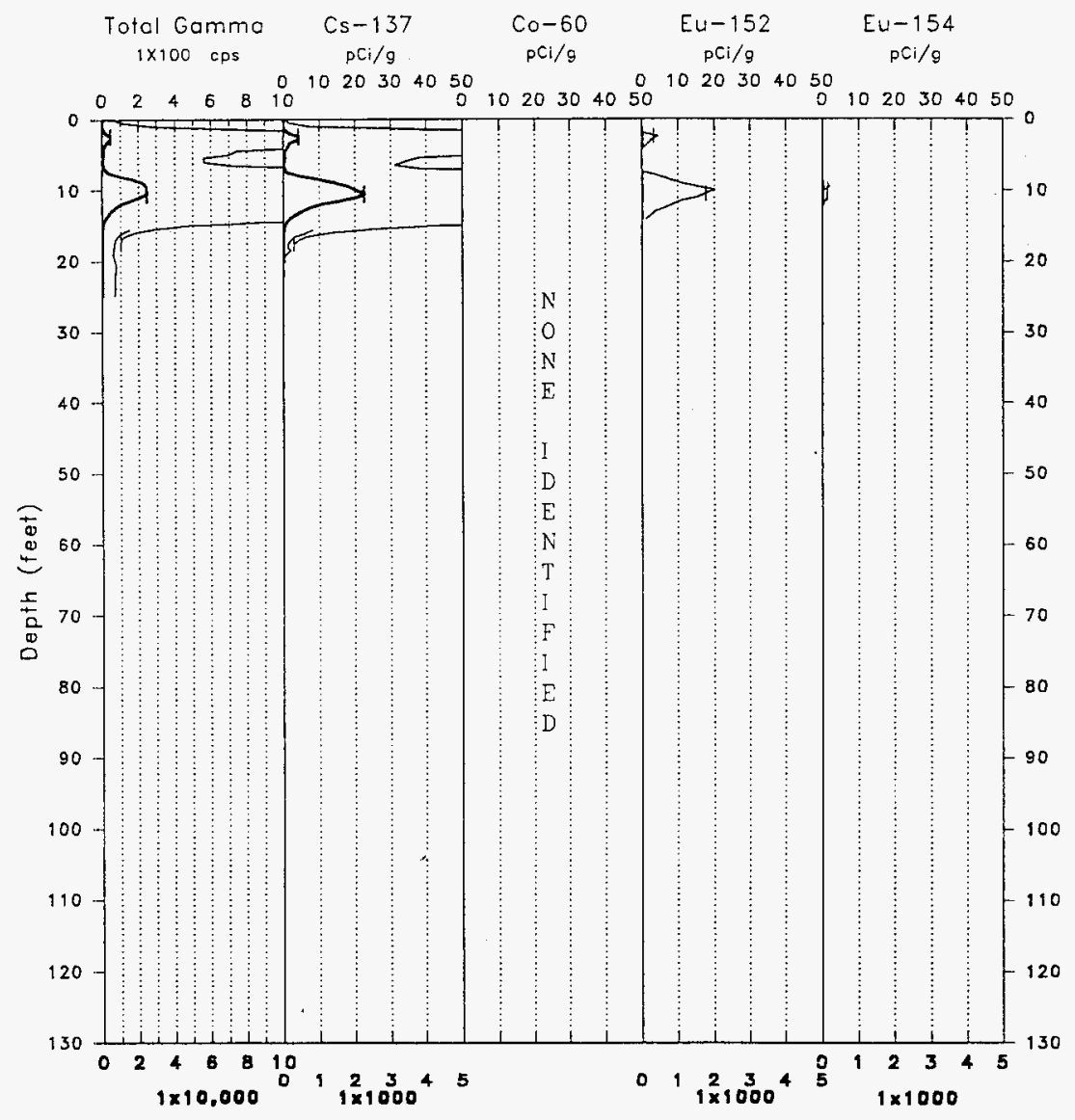


WHC-SD-EN-TI-258, Rev 0

\begin{abstract}
RLS Spectral Gamma-Ray Borehole Survey
Project: $100 \mathrm{FR}-1$

Borehole: $116-\mathrm{F}-4$

Log Date : Feb 25, 1993

Anal Date: Mar 22, 1993
\end{abstract}

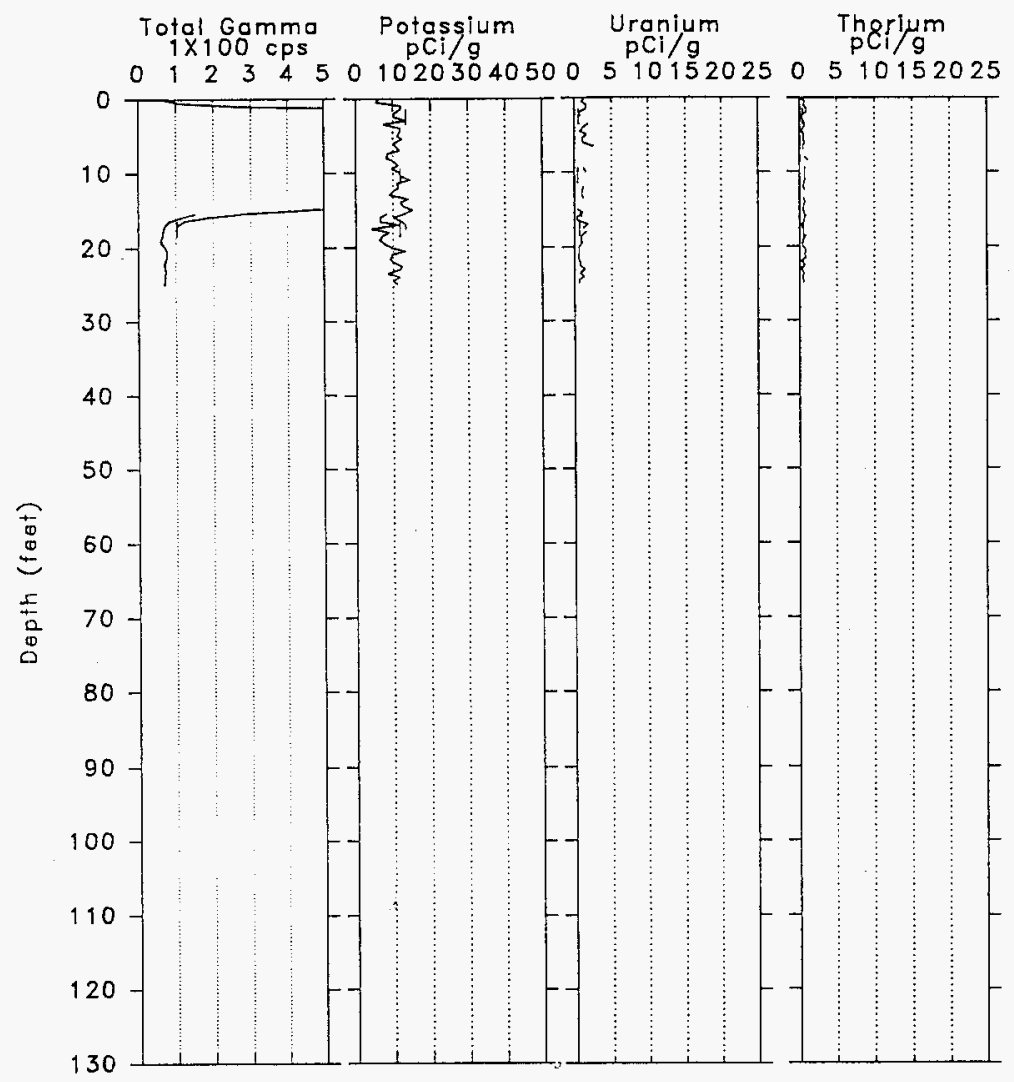




\section{WHC-SD-EN-TI-258, Rev 0}

\section{RLS Borehole Survey Report}

Borehole: $116-F-4$

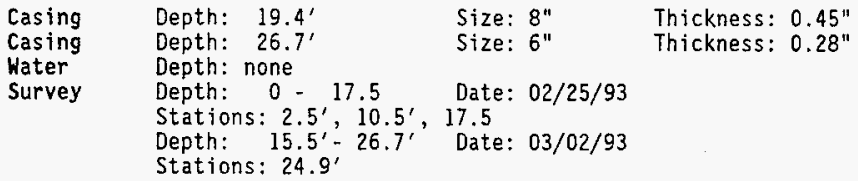

General Notes:

The well was monitored at fixed intervals from 0 to 24.9 feet in increments of 0.5 feet, for real time counting periods of 80 seconds. The well was also monitored at the fixed depths of $2.5,10.5,17.5$, and 24.9 feet for real time counting periods of 300 seconds. As shown on the first plot the man-made radionuclide Cs-137 was observed at depths of from 0 to 22 feet. This radionuclide had two local activity maxima at depths of 2.5 and 10.5 feet. Two other man-made europium radionuclides were observed. Europium-152 was observed at depths of from two to four feet, and from six to 14 feet, with local activity maxima at 2.5 and ten feet. Eu-154 was observed at depths of from nine to 13.5 feet with an activity maximum at about 9.5 feet. The highest activity observed is due to $\mathrm{Cs}-137$, followed in decreasing order by Eu-152 and Eu-154. The total gamma count rate is dominated by and shows the same depth profile as the Cesium activity.

The naturally occurring radionuclides potassium, uranium, and thorium were al so observed throughout the monitored depths of the well. They are present at calculated activity levels which are normal for Hanford soils. These data are shown on the second plot.

The maximum casing correction of 0.40 inches was applied to the survey data. This data was acquired through a single casing whenever possible to minimize the measurement uncertainty. However, the survey on March 2, 1993 from 15.5 to 19.4 feet was recorded through both six and eight inch casings with a combined thickness of 0.73 inches. As a result the calculated radionuclide activities in that interval are underestimated.

Man-made Radionuclides:

Cesium (Cs-137) was detected from 0 to 22 feet. The maximum calculated activities of 435 and $\mathrm{pCi} / \mathrm{g}$ and $2280 \mathrm{pCi} / \mathrm{g}$ occurred at depths of 2.5 and 10.5 feet respectively.

No Cobalt $\left(\mathrm{CO}_{0}-60\right)$ was detected. The plot track is shown for uniformity of presentation on?y.

Europium (Eu-152) was detected from two to four feet with a maximum calculated activity of $5 \mathrm{pCi} / \mathrm{g}$ at 2.5 feet. It was also detected from six to 14 feet with a maximum calculated activity of $20 \mathrm{pCi} / \mathrm{g}$ at ten feet.

Europium (Eu-154) was detected from nine to 13.5 feet with a maximum calculated activity of $2 \mathrm{pC} i / g$ at 9.5 feet. 
Westinghouse Hanford Company RLS Spectral Gamma-Ray Borehole Survey Log Header

Project: $100 \mathrm{FR}-1$

Borehole
Coordinates
Elevation

Borehole Environment Information

\begin{tabular}{|c|c|c|c|}
\hline \multicolumn{2}{|c|}{ Borehole liquid depth none (ft) from zero (0.0) depth reference of log } \\
\hline $\begin{array}{c}\text { Casing size } \\
\text { (in.) }\end{array}$ & $\begin{array}{c}\text { Casing thickness } \\
\text { (in.) }\end{array}$ & $\begin{array}{c}\text { Top depth } \\
\text { (ft) }\end{array}$ & $\begin{array}{c}\text { Base depth } \\
\text { (ft) }\end{array}$ \\
\hline 8 & 0.322 & 0 & 15 \\
\hline 6 & 0.28 & 0 & 25 \\
\hline & & & \\
\hline
\end{tabular}

RLS Passive Spectral Gamma Survey Information

\begin{tabular}{|c|c|c|c|c|}
\hline \multicolumn{5}{|c|}{$\begin{array}{l}\text { Logging Engineers } \frac{\mathrm{J} \text {. E. Meisner }}{\text { Log depth reference at zero }(0.0)} \frac{\mathrm{S} . \mathrm{E} . \text { Kos }}{\text { depth is ground level }} \\
\text { Lo. Kiesler }\end{array}$} \\
\hline Log Date & $\begin{array}{l}\text { Archive } \\
\text { file names }\end{array}$ & Log mode speed & $\begin{array}{l}\text { Depth interv } \\
\text { Top Base } \\
\end{array}$ & $\begin{array}{l}\mathrm{ft}) \\
\text { Incr }\end{array}$ \\
\hline Feb 1,1993 & H116F06\A321 & $80 \mathrm{sec}$ RT & 13. & 0.5 \\
\hline Feb 1,1993 & $\mathrm{H} 115 \mathrm{~F} 06 \backslash \mathrm{A} 321$ & $80 \mathrm{sec}$ RT & 23 & 0.5 \\
\hline Feb 1,1993 & H116F06\A321 & Station $300 \mathrm{sec}$ & $6.5,13,14$, & \\
\hline
\end{tabular}
MSA: Move-Siop-Acquire RT: Real time

Calibration and Analys is Information

RLS Calibration Date: Nov. 21, 1991

Calibration Report: WHC-SD-EN-TRP-001

Analyst Names: W. F. Nicaise R. K. Price

Analys is Date: Feb 10,1993

Analysis Notes: The 6 inch casing was removed between the two surveys. Radionuclides Identified: $C_{S}-137, C_{0}-60, E u-152, E u-154$ 


\section{RLS Spectral Gamma-Ray Borehole Survey}

Project: $100 \mathrm{FR}-1$

Borehole: 116-F-6
Log Date: Feb 02, 1993 Anal. Date: Feb 10, 1993

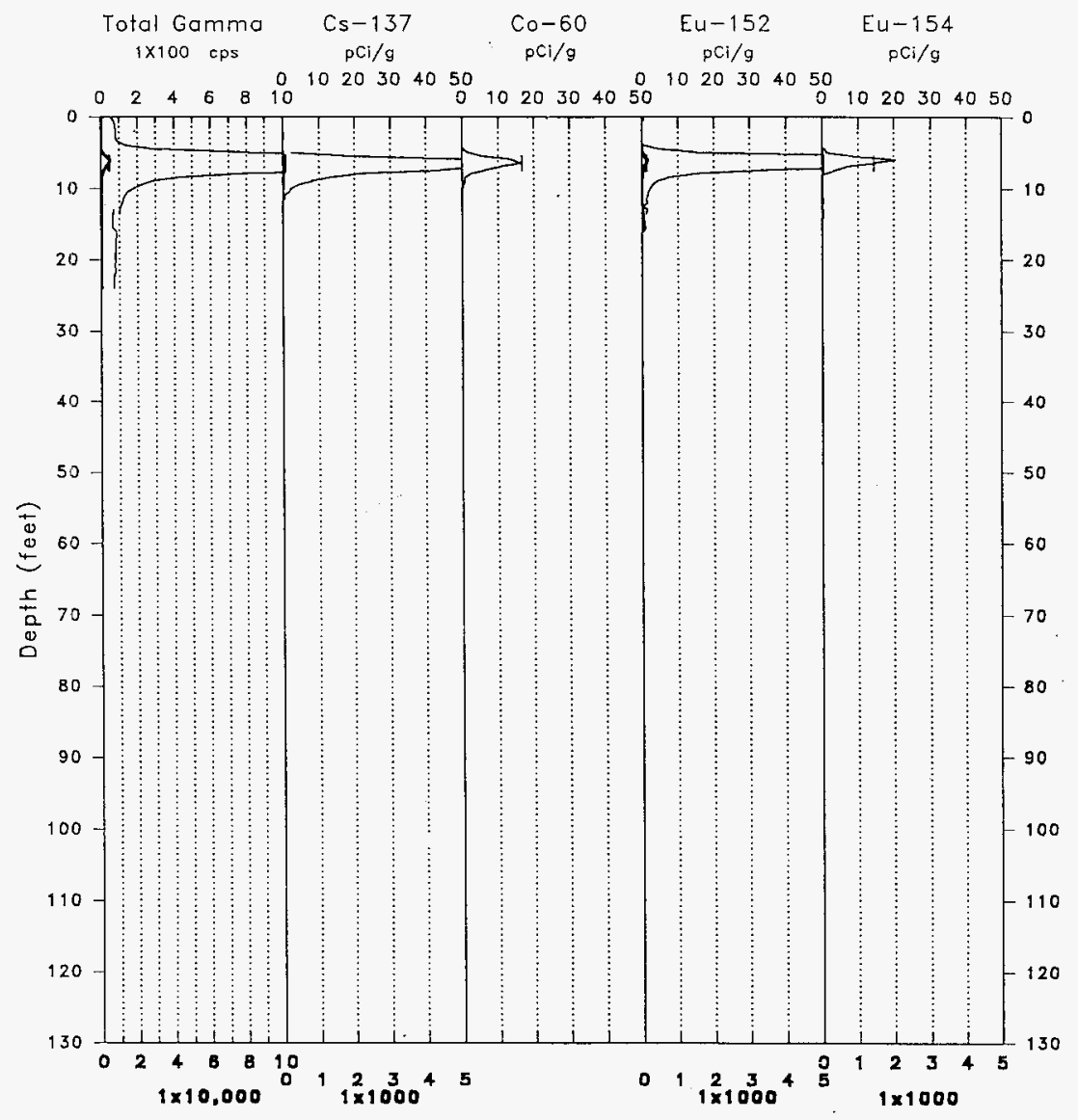


WHC-SD-EN-TI-258, Rev 0

\begin{abstract}
RLS Spectral Gamma-Ray Borehole Survey
Project: $100 \mathrm{FR}-1$

Log Date : Feb 02, 1993

Borehole : $116-F-6$

Anal Date: Feb 10, 1993
\end{abstract}

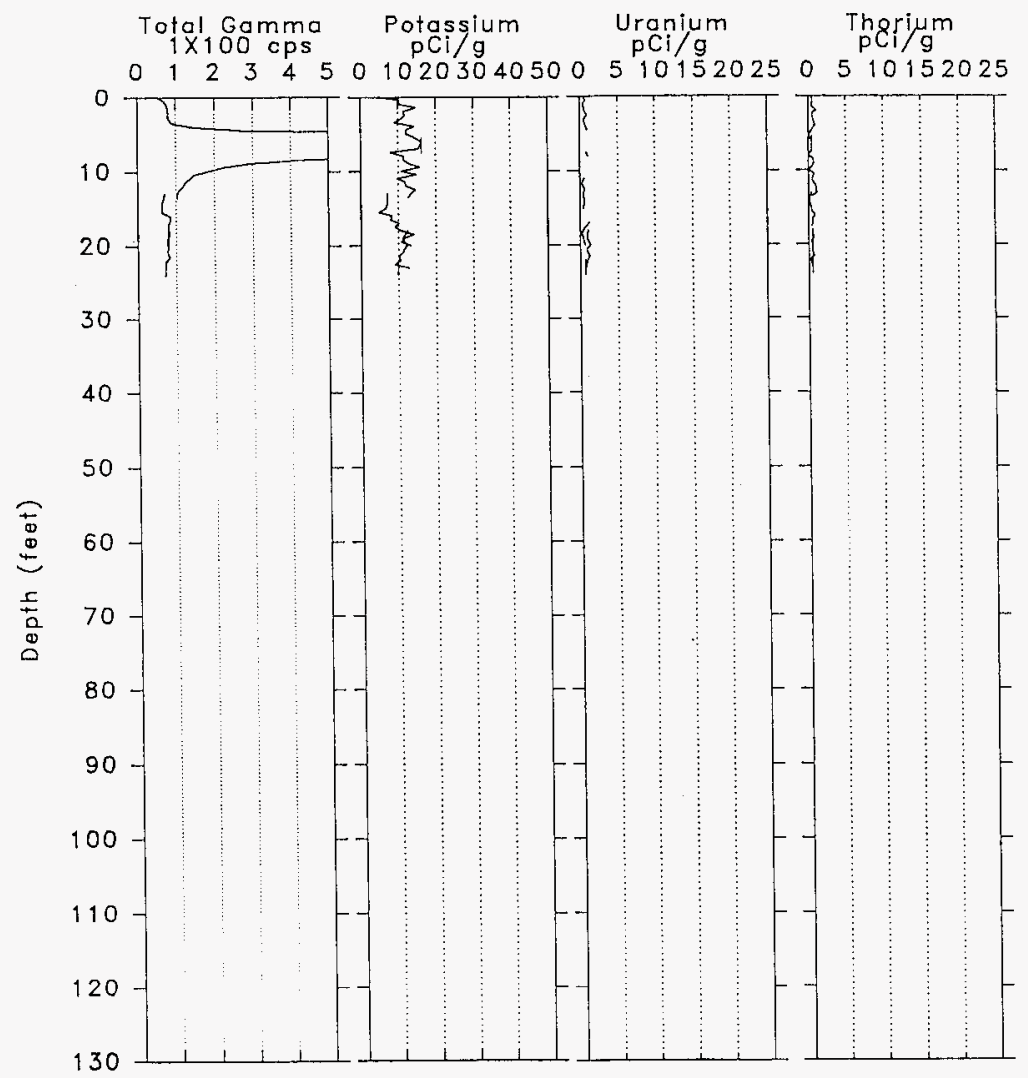




\section{WHC-SD-EN-TI-258, Rev 0}

\section{RLS Barehole Survey Repart}

Borehole: $116-f-6$

Casing Depth: $1^{\prime} 5^{\prime} \quad$ Size: $8^{\prime \prime}$ Thickness: $0.322^{\prime \prime}$

Water

Depth: none

Survey Depth: $0-13.5^{\prime}, 15-23^{\prime}$

Stations: $6.5^{\prime}, 13^{\circ}, 14^{\circ}, 23^{\prime}$

Date: $02 / 01 / 93$

\section{General Notes:}

The well was monitored at fixed intervals from 0 to 13.5 feet, and from 15 , to 23 feet at intervals of 0.5 feet, for real time counting intervals of 80 seconds. Spectra were also acquired at fixed depths of $6.5,13,14$, and 23 feet for real time counting intervals of 300 seconds. Several man-made radionuclides were observed as shown on the first plot. As may be seen on this plot the total gamma count rate as well as the activity of the radionuclides is sharply peaked at a depth of 6.5 feet. There are traces of radionuclide activity down to about 16 feet. The naturally occurring radionuclides potassium, uranium, and thorium are also present at activities which are normal for Hanford soils. This is shown on the second plot.

The log survey was acquired in two intervals in order to maintain only one casing string in the borehole, thus reducing the attenuation of gamma ray activity. The first survey interval was from 15 to 23 feet taken through a 6inch casing. The drilling crew then withdrew the 6 -inch casing, and sealed off the abandoned portion of the borehole. A second $\log$ survey was then acquired from 0 to 13.5 feet taken through the single 8-inch casing.

Man-made Radionuclides:

Cesium ( $\mathrm{Cs}-137$ ) was detected from 5.0 to 15.0 feet. The maximum calculated activity of $74 \mathrm{pCi} / \mathrm{g}$ occurred at a depth of 6.5 feet.

Cobalt $(\mathrm{Co}-60)$ was detected from 4.5 to 10.0 feet. The maximum calculated activity of $18 \mathrm{pCi} / \mathrm{g}$ occurred at a depth of 6.5 feet.

Europium (Eu-152) was detected from 4.0 to 16.0 feet. The maximum calculated activity of $169 \mathrm{pCi} / \mathrm{g}$ occurred at a depth of $6.5 \mathrm{feet}$.

Europium (Eu-154) was detected from 4.5 to 10.0 feet. The maximum calculated activity of $20 \mathrm{pCi} / \mathrm{g}$ occurred at a depth of six feet. 
WHC-SD-EN-TI-258, Rev 0

\section{Westinghouse Hanford Company \\ RLS Spectral Gamma-Ray Borehole Survey Log Header}

Project: $100 \mathrm{FR}-1$

\begin{tabular}{|c|c|c|c|}
\hline Borehole & $-9 C$ & & \\
\hline $\begin{array}{l}\text { Coordinates } \\
\text { Elevation }\end{array}$ & $\frac{N A N}{N A}+\bar{t}$ & $\begin{array}{ll}\text { NA } W & \text { Feet } \\
\text { Top of casing }\end{array}$ & $\begin{array}{l}\text { (Hanford } 100 \text { Area) } \\
\text { (Hanford } 100 \text { Area) }\end{array}$ \\
\hline
\end{tabular}

Borehole Environment Information

\begin{tabular}{|c|c|c|c|}
\hline \multicolumn{2}{|c|}{ Borehole liquid depth none (ft) from zero (0.0) depth reference of log } \\
\hline $\begin{array}{c}\text { - Casing size } \\
\text { (in.) }\end{array}$ & $\begin{array}{c}\text { Casing thickness } \\
\text { (in.) }\end{array}$ & $\begin{array}{c}\text { Top depth } \\
(\mathrm{ft})\end{array}$ & $\begin{array}{c}\text { Base depth } \\
(\mathrm{ft})\end{array}$ \\
\hline 8 & 0.322 & 0 & 26 \\
\hline & & & \\
\hline
\end{tabular}

RLS Passive Spectral Gamma Survey Information

\begin{tabular}{|c|c|c|c|c|c|}
\hline \multicolumn{6}{|c|}{$\begin{array}{l}\text { Logging Engineers } \frac{R . V . C r a m}{\text { L. V. E. Kos }} \\
\text { Log depth reference at zero }(0.0) \\
\frac{\text { depth is ground level }}{\text { J. E. Kiesler }}\end{array}$} \\
\hline Log Date & $\begin{array}{l}\text { Archive } \\
\text { file names }\end{array}$ & Log mode speed & $\begin{array}{l}\text { Depth } \\
\text { Top }\end{array}$ & $\begin{array}{c}\text { interva } \\
\text { Base } \\
\end{array}$ & $\begin{array}{l}(\mathrm{ft}) \\
\text { Iner }\end{array}$ \\
\hline \multirow[t]{2}{*}{ Feb 17, 1993} & H116F09C \A331 & MSA $\quad 80 \mathrm{sec} R T$ & 0 & 26 & 0.5 \\
\hline & & Station $300 \mathrm{sec}$ & & $24 \mathrm{ft}$ & \\
\hline
\end{tabular}

Calibration and Analysis Information

RLS Cal jbration Date: Nov. 21, 1991

Calibration Report: WHC-SD-EN-TRP-001

Analyst Names: W. F. Nicaise

Analysis Date: Jan. 15, 1993

Analysis Notes:

Radionuclides Identified: Cs-137 
WHC-SD-EN-TI-258, Rev 0

RLS Spectral Gamma-Ray Borehole Survey

Project: $100 \mathrm{FR}-1$

Borehole: $116-F-9 C$
Log Date: Feb 17, 1993 Anal. Date: Feb 26, 1993

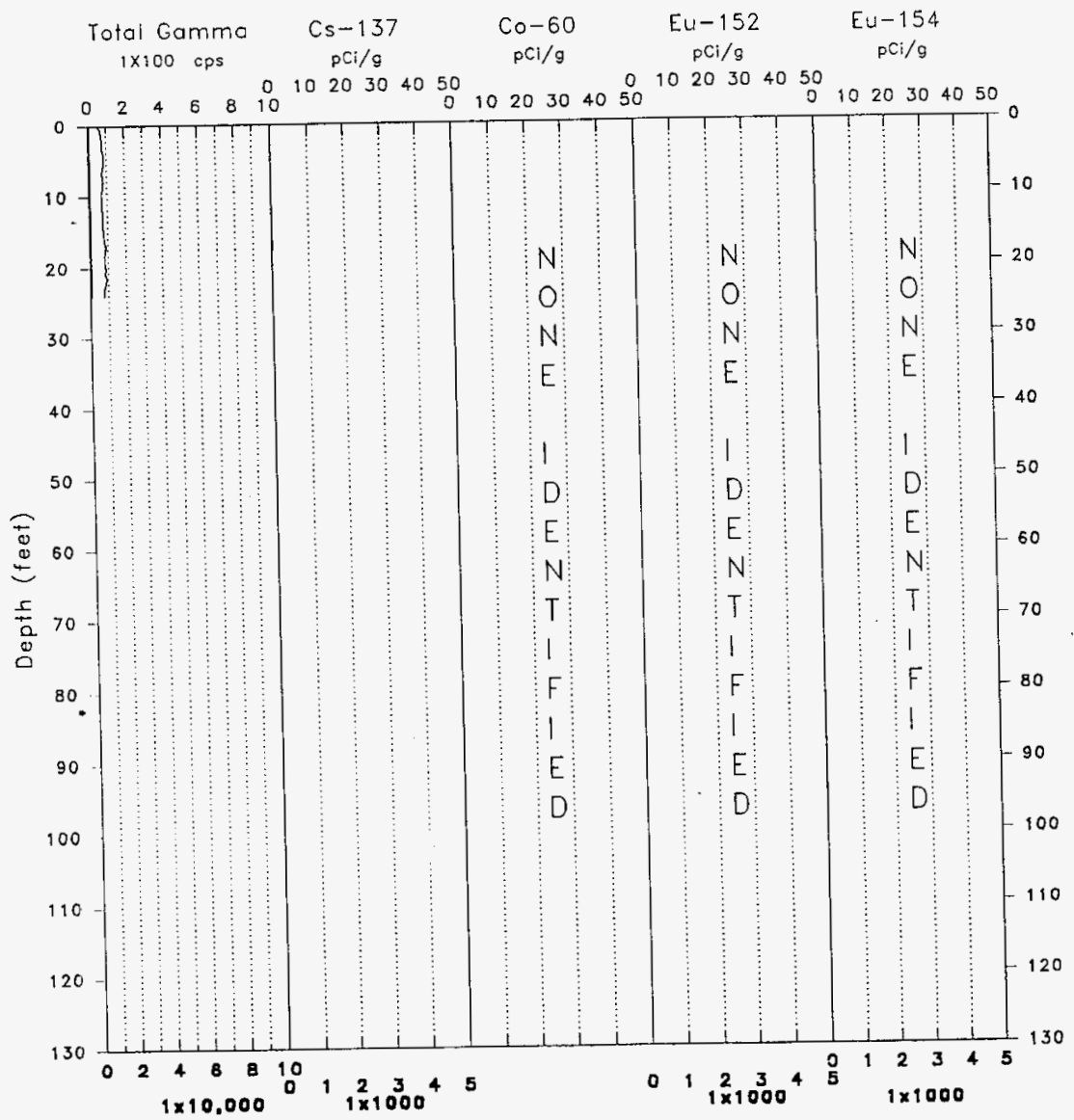


RLS Spectral Gamma-Ray Borehole Survey

Project: 100 FR -1

Borehole : $116-F-9 \mathrm{C}$
Log Date : Feb 17, 1993

Anal Date: Feb 26, 1993

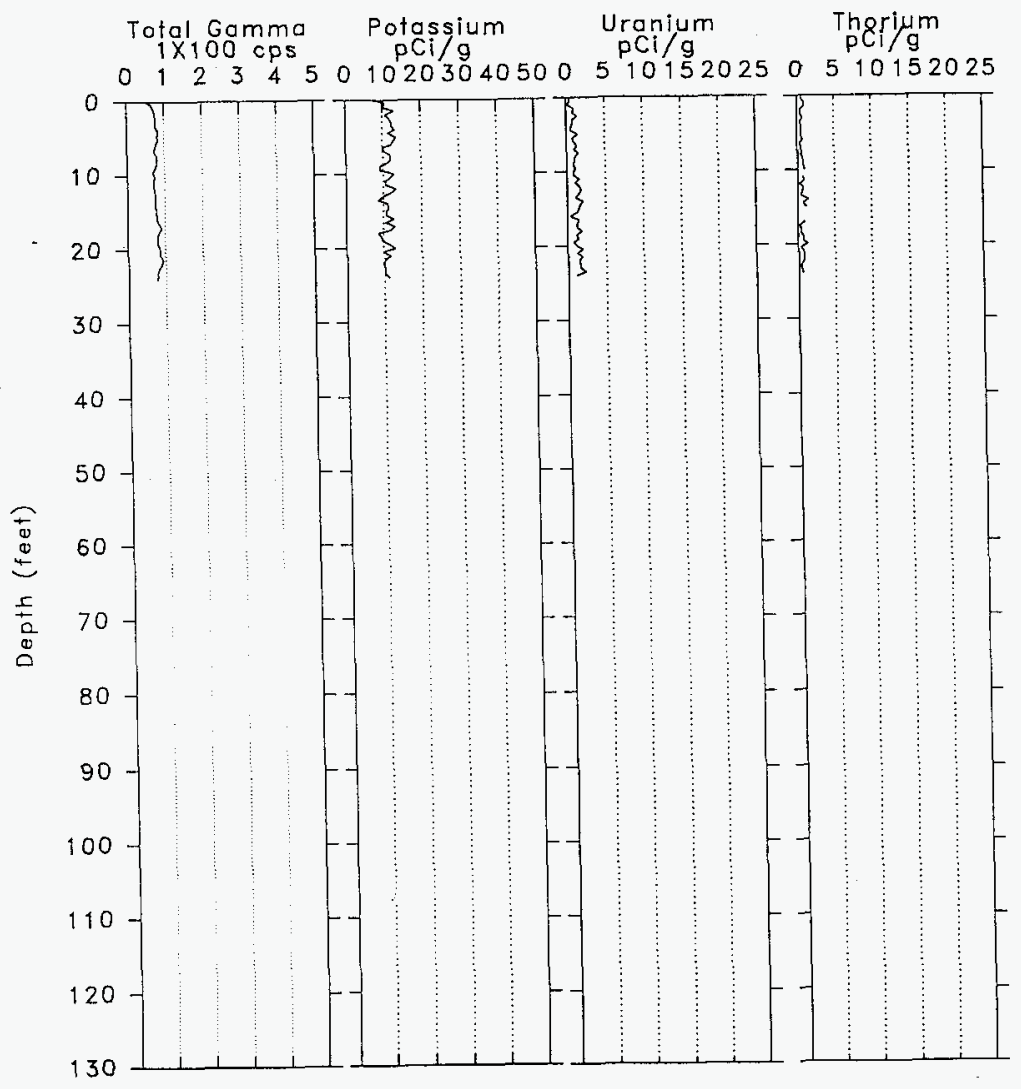




\section{WHC-SD-EN-TI-258, Rev 0}

\section{RLS Borehole Survey Report}

Borehole: $116-F-9 C$

$\begin{array}{llll}\text { Casing } & \text { Depth: } 26^{\prime} & \text { Size: } 8^{\prime \prime} & \text { Thickness: } 0.322^{\prime \prime} \\ \text { Water } & \text { Depth: none } & & \\ \text { Survey } & \text { Depth: } 0-23.5^{\prime} & \text { Date: } 02 / 17 / 93 & \\ & \text { Stations: } 24^{\prime} & & \end{array}$

\section{General Notes:}

The well was monitored from 0 to 24 feet at fixed intervals of 0.5 feet. The spectra were collected for real time intervals of 80 seconds, except for the 24 foot station the counting time of which was 300 seconds. The naturally occurring radionuclides potassium, uranium, and thorium are present at activities which are normal for Hanford soils. The total gamma ray count rate reflects this. There was a trace of $\mathrm{Cs}-137$ detected, near the limit of the system sensitivity for low level activity at a well depth of 17 feet. The Cesium is shown on the first plot and the naturally occurring radionuclides are shown on the second plot.

Man-made Radionuclides: Cesium (Cs-137) was detected from 16.5 to 17.5 feet. The activity observed at this depth is $0.3 \mathrm{pCi} / \mathrm{g}$.

No other man-made radionuclides were observed. 


\section{WHC-SD-EN-TI-258, Rev 0}

\section{Westinghouse Hanford Company \\ RLS Spectral Gamma-Ray Borehole Survey Log Header}

Project: $100 \mathrm{FR}-1$

Borehole Coordinates Elevation

$$
\frac{116-\mathrm{F}-14}{\mathrm{NAN}} \mathrm{NA}
$$

NA W

Feet (Hanford 100 Area) Top of casing (Hanford 100 Area)

Borehoie Environment Information

\begin{tabular}{|c|c|c|c|c|}
\hline \multicolumn{5}{|c|}{$\begin{array}{l}\text { Logging Engineers } R . V \text {. Cram } \\
\text { Log depth reference at zero }(0.0)\end{array}$} \\
\hline Log Date & $\begin{array}{c}\text { Archive } \\
\text { file names }\end{array}$ & Log mode speed & $\begin{array}{l}\text { Depth interva } \\
\text { Top Base }\end{array}$ & $\begin{array}{l}\text { (ft) } \\
\text { Incr }\end{array}$ \\
\hline Mar 04, 1993 & $\mathrm{H} 116 F 14 \backslash \mathrm{A} 338$ & MSA 80 sec RT & 23 & 0.5 \\
\hline Mar 04, 1993 & $H 116 F 14 \backslash A 338$ & Station $300 \mathrm{sec}$ & $4^{\prime}, 13^{\prime}, 23.5^{\prime}$ & \\
\hline
\end{tabular}

\begin{tabular}{|c|c|c|c|}
\hline \multicolumn{2}{|c|}{ Borehole liquid depth none (ft) from zero (0.0) depth reference of log } \\
\hline \hline $\begin{array}{c}\text { Casing size } \\
\text { (in.) }\end{array}$ & $\begin{array}{c}\text { Casing thickness } \\
\text { (in.) }\end{array}$ & $\begin{array}{c}\text { Top depth } \\
\text { (ft) }\end{array}$ & $\begin{array}{c}\text { Base depth } \\
\text { (ft) }\end{array}$ \\
\hline 8 & 0.322 & 0 & 25 \\
\hline 10 & 0.365 & 0 & 15.7 \\
\hline
\end{tabular}

RLS Passive Spectral Gamma Survey Information

RT: Real time

\section{Calibration and Analysis Information}

RLS Calibration Date: Nov. 21, 1991

Calibration Report: WHC-SD-EN-TRP-001

Analyst Names: W. F. Nicaise

Analysis Date: Mar. 26, 1993

Analys is Notes: 8" casing logged 12-23'\&puTled; 10" casing logged 0-13'. Radionucl ides Identified: $C_{S}-137, C_{0}-60, E u-152, E u-154$ 


\section{RLS Spectral Gamma-Ray Borehole Survey}

$$
\text { Project: } 100 \mathrm{FR}-1
$$

Borehole: $116-F-14$
Log Date: Mar 04, 1993

Anal. Date: Mar 26, 1993

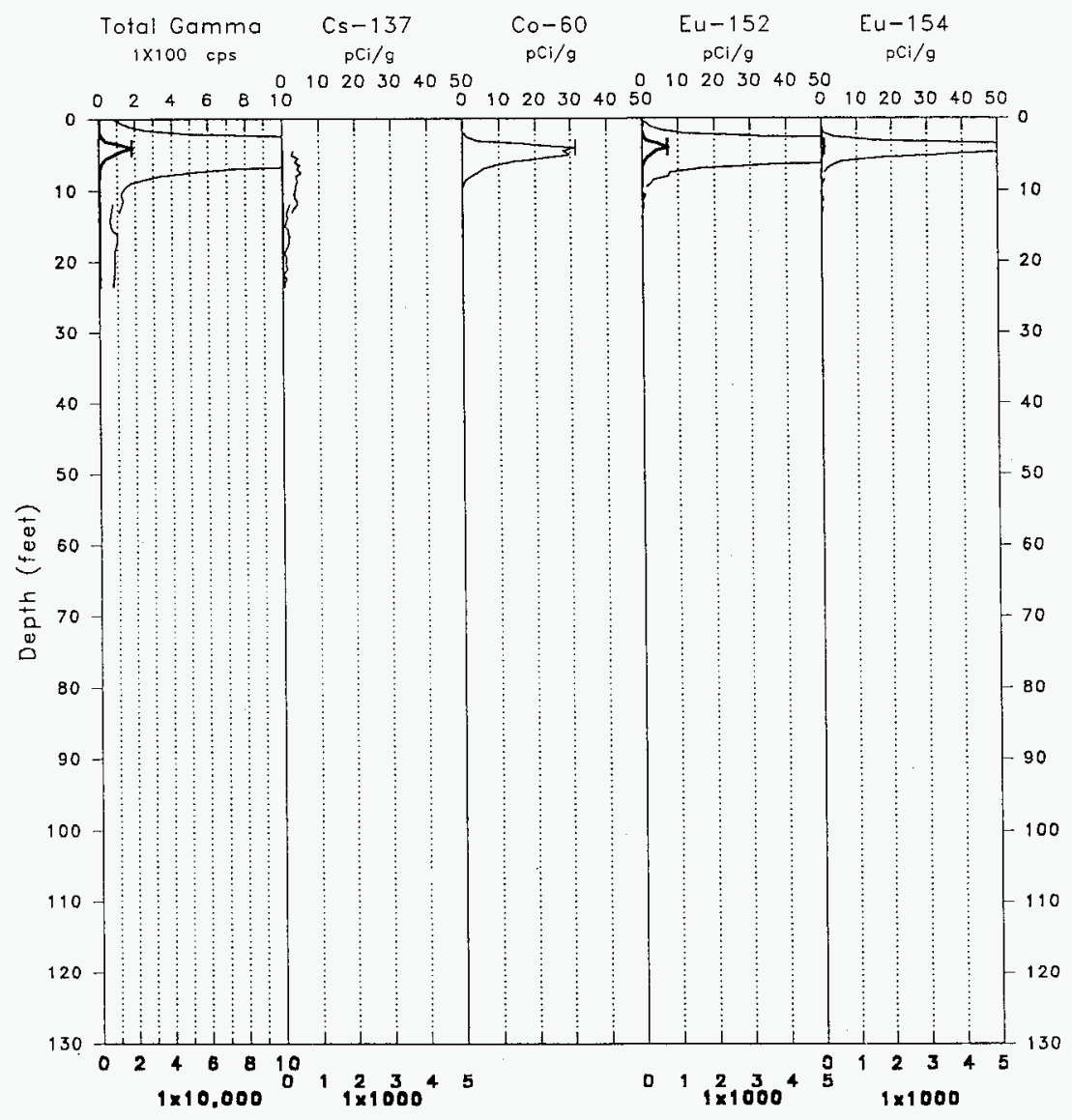


WHC-SD-EN-TI-258, Rev 0

\begin{abstract}
RLS Spectral Gamma-Ray Borehole Survey
Project: $100 \mathrm{FR}-1$

Borehole : $116-F-14$

Log Date : Mar 04, 1993

Anal Date: Mar 26, 1993
\end{abstract}

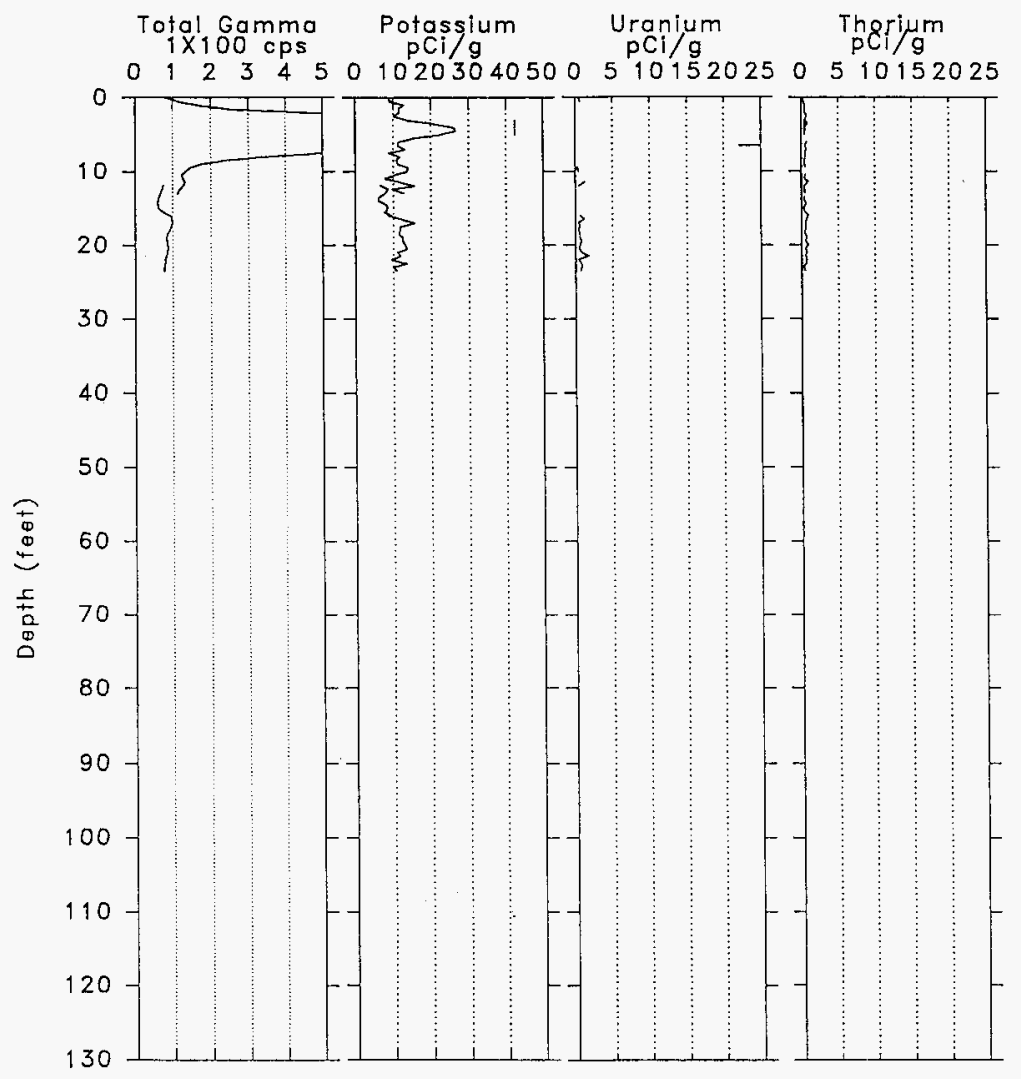


WHC-SD-EN-TI-258, Rev 0

RLS Borehole Survey Report

Borehole: $116-F-14$

$\begin{array}{llll}\text { Casing } & \text { Depth: 25, } & \text { Size: 8" } & \text { Thickness: } 0.322^{\prime \prime} \\ \text { Casing } & \text { Depth: 15.7, } & \text { Size: 10" } & \text { Thickness: } 0.365^{\prime \prime} \\ \text { Water } & \text { Depth: none } & & \\ \text { Survey } & \text { Depth: 0 - 23, } & \text { Date: 03/04/93 } & \\ & \text { Stations: 4', 13', 23.5 } & \end{array}$

\section{General Notes:}

The weil was monitored from 23 to 12 feet in increments of 0.5 feet for counting periods of 80 seconds. The eight inch casing was then withdrawn and the well was logged through the ten inch casing from 13 to 0 feet in increments of 0.5 feet for counting periods of 80 seconds. The man-made radionuclides Cesium-137, Coba1t-60, Europium-152 and Europium-154 were observed in the well regions monitored, with the activity profiles shown in the first plot. The total gamma ray count rate to a depth of 13 feet is dominated by and has the same depth profile as the two europium radionuclides, Eu-152 which is the more intense, and Eu-154. Then Co-60 and the least active Cs-137 contribute to the observed count rate. However below 13 feet the total gamma count rate profile is due to Cs-137.

The naturally occurring radionuclides potassium, uranium, and thorium were al so observed throughout the monitored depths of the well as shown on the second plot. The uranium and thorium are present at activity levels which are normal for Hanford soils. However potassium shows an uncharacteristic activity at four feet which is higher than normal. Since this high activity zone occurs at the same depth as the highest concentration of Eu-152, and since Eu-152 has a gamma ray peak at nearly the same energy as the single potassium peak ( $1460 \mathrm{keV}$ ), it can be shown that this Eu-152 peak is the source of the anomalously high apparent potassium activity. The Eu-152 gamma ray peak at $1458 \mathrm{keV}$ contributes the equivalent of about $3 \mathrm{pCi} / \mathrm{g}$ to the potassium gamma ray activity for each $100 \mathrm{pCi} / \mathrm{g}$ of Eu-152.

Man-made Radionuclides:

Cesium (Cs-137) was detected from 4.5 to 23.5 feet. The maximum calculated activity of $5 \mathrm{pCi} / \mathrm{g}$ occurred from 6.5 to 7.5 feet.

Cobalt $(C 0-60)$ was detected from 0.5 to 9.5 feet. The maximum calculated activity of $31 \mathrm{pCi} / \mathrm{g}$ occurred at four feet.

Europium (Eu-152) was detected from 0.5 to 13 feet. The maximum calculated activity of $730 \mathrm{pCi} / \mathrm{g}$ occurred at four feet.

Europium (Eu-154) was detected from 0 to 12.5 feet. The maximum calculated activity of $92 \mathrm{pCi} / \mathrm{g}$ occurred at four feet. 
WHC-SD-EN-TI-258, Rev 0

\section{APPENDIX B}

\section{THE RLS SYSTEM}

The Radionuclide Logging System (RLS) is a passive, high-resolution, gamma-ray energyspectrum, in-borehole logging system. The system utilizes a semi-conducting crystal of high-purity germanium (HPGe); the crystal is cooled during logging with liquid nitrogen, and an electrical potential is imposed across the crystal. Gamma-ray interactions with the crystal produces sharp electrical pulses with energies correlative to the energies of the impinging gamma rays, resulting in excellent gamma-ray energy resolution. This in turn, allows for the direct identification of the radionuclides from which those gamma rays were emitted. With appropriate calibration, concentrations of the gamma-ray-emitting radionuclides surrounding the borehole can be assayed, as well as identified.

The logging cable equipped on the RLS was specifically designed for the system. It suspends the detector in the well, conducts power to the detector, receives electrical signals from the detector, and provides the conduit for venting the liquid nitrogen component of the detector. Errors in the depth- measuring system of the RLS are mainly related to cable stretch, cable and sheave wheel contact, and electronic encoding components. The recorded depth of the detector is estimated to be accurate to 98.5 percent, with a precision (repeatability) of 99 percent. Comparisons with drilling measurements, other logging equipment, and secondary measuring systems have verified the accuracy. An upgrade in the logging cable and measuring system is being investigated.

There are two configurations in which the logging sonde can be used. One is the as-built state (standard) and the other (alternate) is with an external "shield" (gamma-ray absorbing material) placed around it.

The standard logging configuration optimizes the counting system for detecting low decay activities of radioelements. The RLS has frequently detected man-made radioelement activities of 0.3 $\mathrm{pCi} / \mathrm{g}$ for nuclides emitting gamma rays having energies greater than $500 \mathrm{keV}$ and the number of gamma-rays emitted per decay being at least one for each two decays (greater than 50 percent. The maximum decay activity the RLS has detected is about $10,000 \mathrm{pCi} / \mathrm{g}$ in this standard configuration.

The alternate logging configuration at present employs a lead shield and changes the counting system to maximize the count rate. Configuring the counting system to maximize the count rate compromises its ability to detect radioelements at low decay activities (concentrations). The RLS has frequently detected man-made radioelement activities exceeding $33,000 \mathrm{pCi} / \mathrm{g}$ in this shielded configuration. The alternate logging configuration was not employed for the surveys included in this report because of the low count rates encountered. 
WHC-SD-EN-TI-258, Rev 0

\section{Limitations to the Radioelement Analyses}

The borehole surveys presented in this report have all been analyzed using the calibration data acquired in November 1991. Calculation of the calibration factors used in data reduction depend on the calibration data and on nuclear data (half-lives, branching ratios, number of gamma-rays per decay) for the particular nuclide. All of the nuclear data were taken from Erdtmann and Soyka (1979).

Borehole-environment correction factors have been determined for steel casing and water in the borehole. Correction factors for other borehole configurations have not been investigated. Borehole configurations for which no correction is available include: (1) grout between multiple casing strings, (2) formation seals containing bentonite, sand, or grout behind the casing, and (3) drilling mud remaining inside the borehole during logging. The calculated decay activity for manmade radionuclides will be underestimated for boreholes with these configurations.

Energy-dependent casing corrections have been established for steel casing thicknesses up to 0.40 inches. Corrections for casings of different materials and/or cumulative thicknesses greater than 0.40 inches have not been calculated and therefore cannot be used in the data reduction.

The calibration data were recorded with the detector centered in calibration zones that are uniform in density, water content, and gamma-ray source material. The dimensions of each zone are large enough that the detector always responded as though surrounded by a medium of infinite extent. Therefore, the use of the calibration results to calculate nuclide activity carries the assumption that the nuclides in the logged formation are also distributed in thick uniform layers. Gamma-ray sources are not normally distributed in the earth in thick uniform layers. Source inhomogeneities are reflected to some degree by the fluctuations in the amplitudes of the log traces. A factor called the "vertical spacial resolution" quantifies the correlation between (1) the amplitude of the log fluctuation and the depth interval over which it extends, and (2) the intensity of the corresponding gamma-ray source and the thickness of the zone in which the source is embedded. The vertical spatial resolution of the RLS HPGe logging system is scheduled for investigation.

Radionuclide decay activities are determined from the net area of the gamma-ray peaks. Radioelements, such as strontium-90, which do not emit a gamma ray when they decay will not be identified or quantified by the spectral analysis performed for this report. The decay of strontium-90 results in a high-energy beta particle that can excite surrounding elements to emit photon radiation that can be identified by the HPGe detector. This type of radiation is called "bremsstrahlung" radiation. A method to obtain estimates of the concentrations of strontium- 90 is under consideration. 


\section{DISTRIBUTION SHEET}

\begin{tabular}{|c|c|c|c|c|c|}
\hline \multirow{2}{*}{$\begin{array}{l}\text { To } \\
\text { Distribution }\end{array}$} & \multirow{2}{*}{\multicolumn{3}{|c|}{$\begin{array}{l}\text { From } \\
\text { J.W. Fassett }\end{array}$}} & \multicolumn{2}{|l|}{ Page 1 of 1} \\
\hline & & & & \multicolumn{2}{|c|}{ Date $9 / 10 / 96$} \\
\hline \multicolumn{4}{|l|}{ Project Title $/$ Work Order } & \multicolumn{2}{|c|}{ EDT No. $\quad 610770$} \\
\hline \multicolumn{4}{|c|}{$\begin{array}{l}\text { WHC-SD-EN-TI-258, Spectral Gamma-Ray Logging Report for the } \\
\text { Six New Characterization Boreholes in the } 100-\text { FR-1 Operable Unit }\end{array}$} & \multicolumn{2}{|c|}{ ECN No. $N / A$} \\
\hline Name & MSIN & $\begin{array}{c}\text { Text } \\
\text { With All } \\
\text { Attach. }\end{array}$ & Text Only & $\begin{array}{l}\text { Attach./ } \\
\text { Appendix } \\
\text { Only }\end{array}$ & $\begin{array}{c}\text { EDT/ECN } \\
\text { Only }\end{array}$ \\
\hline
\end{tabular}

J. W. Fassett

J. I. Feaster

$\begin{array}{ll}H 6-06 & X \\ H 6-06 & X \\ N 1-55 & X\end{array}$

R. K. Price

$\mathrm{Nl}-55$

$x$

Central Files (2)

EDMC (2)

A3-88

H6-08

$x$

$x$ 